SANTOS, Elza Cristina. Dimensão lúdica e arquitetura: o exemplo de uma escola de educação infantil em Uberlândia. Thésis, Rio de Janeiro, v. 2, n. 2, p. 91-132, jul./dez. 2016

data de submissão: 07/05/2016 data de aceite: $25 / 08 / 2016$

\section{Dimensão lúdica e arquitetura: o exemplo de uma escola de educação infantil em Uberlândia} Elza Cristina Santos

Elza Cristina Santos é doutora em Arquitetura e Professora da FAUED-UFU | elzacristina@hotmail.com

\section{Resumo}

O projeto para uma escola infantil desencadeou-se a partir desta problemática: por que as escolas não oferecem espaços de qualidade eficientes à educação infantil? Como resposta, sugeriu-se que o edifício escolar, além de apresentar uma solução espacial adequada a uma proposta pedagógica, deveria considerar o brincar como atividade importantíssima no processo de ensino-aprendizagem. Considerou-se as hipóteses de que a maioria das escolas não apresenta espaços apropriados para a educação das crianças e que a atividade lúdica e um espaço escolar complexo são essenciais nesse processo. A comprovação dessas hipóteses convergiu para uma ideia que abrange os conceitos de acolhimento, complexidade, polivalência, transparência e ludicidade, determinantes das diretrizes do projeto: integração com a comunidade; desenho aberto/interação com o meio natural; escola como uma pequena comunidade de aprendizagem; iluminação e ventilação natural; ambientes acolhedores; circulação como um passeio de aprendizagem; adaptabilidade/flexibilidade/variedade; transparência e supervisão passiva; arquitetura que ensina/sustentabilidade; espaços externos e incentivos lúdicos; materiais, texturas e cores como elementos de identidade.

Palavras-chave: escolas (arquitetura), projeto de arquitetura, espaço escolar, lúdico.

\begin{abstract}
The project to an early childhood school started from this problematic: why do not schools offer efficient quality spaces to early childhood education? As an answer, it was suggested that the school building, besides presenting a fitting spatial solution to a pedagogical proposition, should consider playing as a very important activity in the learning process. Have been considered the hypothesis that most schools do not present appropriate environments for child education and that playful activity in a complex scholar space is essential to this process. The confirmation of these hypothesis led to an idea which embraces the concepts of reception, complexity, versatility, transparence and playfulness, determinative to the project guidelines: integration with the community; open sketch/nature interaction; school as a small learning community; natural lighting and ventilation; cozy environments; walking as a learning tour; adaptability/flexibility/variety; transparence and passive supervision; architecture that teaches/sustainability; exterior spaces and playful stimulus; material, textures and colors as identity elements
\end{abstract}

Keywords: schools (architecture), architecture projects, scholar space, playful.

\section{Resumen}

El proyecto para una escuela infantil se desató a partir de este problema: ¿por qué las escuelas no ofrecen espacios de calidad eficiente a la educación infantil? En respuesta, se sugirió que el edificio de la escuela, además de presentar una solución espacial adecuada de una propuesta pedagógica, debe considerar la ac- 
tividad lúdica como una actividad sumamente importante en el proceso de enseñanza y aprendizaje. Se consideró las hipótesis de que la mayoría de las escuelas no tienen espacios adecuados para la educación de los niños y que la actividad del juego y el espacio de la escuela son esenciales en este proceso. La prueba de estas hipótesis se reunieron en una idea que abarca los conceptos de la recepción, complejidad, versatilidad, transparencia y ludicidad, determinantes de las directrices del proyecto: la integración con la comunidad; diseño abierto/interacción con el entorno natural; la escuela como una pequeña comunidad de aprendizaje; iluminación y ventilación natural; ambientes acogedores; la circulación como un recorrido de aprendizaje; adaptabilidad/flexibilidad/diversidad; la transparencia y la vigilancia pasiva; arquitectura que enseña/sostenibilidad; espacios al aire libre y los incentivos lúdicos; materiales, texturas y colores como elementos de identidad

Palabras-clave: escuelas (arquitectura), proyecto de arquitectura, despacio de escuelas, lúdico

\section{Introdução}

Este trabalho apresenta as reflexões teóricas de uma Epesquisa na área de projeto de arquitetura, cuja investigação teve como ponto de partida o interesse em estudar aspectos gerais que envolvem o tema arquitetura e educação e, por objetivo, compreender o espaço escolar, contextualizado e delimitado nas escolas que atendem a crianças de zero a seis anos de idade e elaborar um projeto de arquitetura para uma escola de educação infantil, que apresente soluções com qualidade espacial, lúdica e ambiental necessárias à aprendizagem e ao desenvolvimento infantil.

Embora haja muitos estudos sobre a importância da dimensão espacial das atividades relacionadas à educação, este assunto ainda não foi esgotado; sendo assim, colocou-se em questão uma problemática envolvendo especialmente as escolas públicas de educação infantil: por que essas escolas não oferecem espaços de qualidade eficientes e adequados à educação infantil, mesmo quando se percebe que existe uma relação de afinidade entre o projeto pedagógico adotado e o edifício escolar?

Como resposta para esse questionamento, que também se apresenta como um problema arquitetônico, sugeriu-se que o edifício escolar, muito além de apresentar uma resposta espacial adequada para a realização e aplicação de um determinado projeto pedagógico, deveria considerar também o brincar como uma atividade importantíssima no processo de aprendizagem infantil, e deveria, portanto, apresentar soluções que contemplassem essa necessidade.

Delineado o problema e considerando o senso comum de que a criança aprende brincando, que para brincar 
é necessário espaço, e que os espaços de brincar das cidades estão se tornando espaços do automóvel e da violência, o espaço escolar torna-se ainda mais relevante, já que é nas escolas que as crianças passam a maior parte do seu tempo. E no espaço escolar que as crianças poderão recuperar os espaços de brincar perdidos nas cidades.

Considerou-se as hipóteses de que a maioria das escolas de educação infantil não apresenta espaços de qualidade para a educação das crianças; que a atividade lúdica é essencial no processo de desenvolvimento e aprendizagem infantil e que um espaço escolar complexo e polivalente se apresenta como um agente facilitador do processo de ensino-aprendizagem.

Embasada em autores como Hertzberger, Rapoport, Lynch, Tuan, Frago e Escolano e em pesquisas que envolvem esse tema, a investigação considerou conceitos importantes relativos à qualidade do espaço na arquitetura e à importância da percepção na relação criança-ambiente.

Dos estudos relacionados à qualidade dos espaços na arquitetura (Zevi, Hertzberger, Coelho Neto) ficou claro que é importante oferecer aos usuários espaços que determinem uma interação positiva entre eles e entre eles e a arquitetura. Verificou-se que essa interação pode ser facilitada e otimizada pela percepção sensorial (Hall, Tuan, Lynch, Rapoport), já que os estímulos recebidos pelos sistemas receptores da visão, audição, olfato e tato intensificam a relação homem -ambiente, colaborando desta forma, na apreensão e identificação dos lugares pelas pessoas.

Os estudos do lúdico (Brougère, Huizinga, Kishimto, Bomtempo, Friedmann, Mazzilli e Tornquist) possibilitaram uma visão mais aprofundada da importância do brincar na vida das crianças e comprovaram a hipótese de que a atividade lúdica é essencial para o desenvolvimento e a aprendizagem infantil, pois estimula nas crianças a linguagem, o pensamento, a socialização, a exploração, a invenção, a motricidade, a imaginação e a fantasia.

Complementando esses estudos, as pesquisas de Frago e Escolano, Lima, Castro, Elali, Mazzilli, Bastianini, Chicco e Mela ajudaram na comprovação da hipótese de que um espaço escolar complexo e polivalente se apresenta como um agente facilitador do processo de ensino-aprendizagem.

Essa ideia fundamenta-se nos pressupostos teóricos da construção do conhecimento elaborados por Piaget, 
segundo o qual a pessoa aprende consigo mesma e vai construindo seu conhecimento a partir de interações com o ambiente. Essa construção começa desde o nascimento e se estende por toda a vida. Daí a importância dada aos lugares que recebem as crianças, visto que a inteligência delas pode ser afetada pela interação com o espaço, especialmente nos primeiros anos de vida. Essa experiência espacial deverá influenciar o processo de aprendizagem e o desenvolvimento infantil, tanto no aspecto físico quanto no aspecto sócioemocional e intelectual.

Esses estudos demonstram que o brincar e o espaço são fundamentais na formação das crianças. O espaço propicia a oportunidade de brincar, e o brincar livremente num determinado espaço facilita à criança o desenvolvimento do movimento, da inteligência e das relações sociais e afetivas, e permite o reconhecimento e a conquista do espaço.

A hipótese de que a maioria dos estabelecimentos destinados às escolas de educação infantil não apresentam espaços de qualidade para as crianças de 0 a 6 anos foi comprovada nas visitas às escolas de educação infantil públicas da cidade de Uberlândia. Nessas visitas, verificou-se que as potencialidades dos espaços não foram exploradas, e que a arquitetura era monótona, desinteressante, fria e padronizadora, tanto na forma quanto na organização dos ambientes, oferecendo às crianças poucas oportunidades de se envolverem em atividades lúdicas, ou seja, poucas oportunidades para uma educação interativa de qualidade, adequada à educação infantil.

A partir da comprovação dessas hipóteses chegou-se a uma ideia central, síntese das diversas discussões abordadas na pesquisa, que abrange os conceitos de acolhimento, complexidade, polivalência, transparência e ludicidade. Esses conceitos fundamentaram a tese de que a dimensão lúdica dos espaços escolares - aquelas qualidades que os tornam mais interativos, atraentes, estimulantes e acolhedores - contribui para um ambiente que promove a relação entre seus usuários, corresponde às necessidades da criança, participa e interage com a construção de seu conhecimento.

\section{Acolhimento}

Sabe-se que crianças pequenas vivenciam a entrada na escola com muita emoção e ansiedade, e que é tarefa de educadores e, porque não dizer, de arquitetos atenuar os efeitos negativos que a separação casa-escola gera no comportamento infantil. 
É necessário um período para que as crianças se adaptem ao ambiente escolar. Neste de adaptação, as crianças se esforçam para sentir-se bem e conviver com pessoas, regras e limites distintos daqueles experimentados no espaço doméstico; mas, ainda assim, é responsabilidade da instituição facilitar este processo, acolhendo e cuidando para que elas tenham o conforto físico e emocional de que necessitam. É a qualidade do acolhimento oferecida que garantirá a qualidade da adaptação. Não se trata de uma opção pessoal, ou seja, do quanto a criança se esforça, mas de compreender que há uma relação entre os movimentos tanto da criança quanto da instituição dentro de um mesmo processo.

Neste sentido, o acolhimento na pré-escola torna-se uma questão importante a ser observada, não apenas na esfera da educação, mas também na esfera da arquitetura.

Zevi (1994) verifica a importância dada ao espaço na arquitetura, em especial ao espaço interior, que só poderá ser compreendido se experienciado pelo homem. Zevi (1994) lembra que as atividades e a movimentação do homem no espaço conferem a ele a sua integralidade.

Hertzberger (1996) afirma que a boa arquitetura é aquela que, por permitir várias associações e assumir diversos significados, determina uma interação positiva entre seus usuários e entre estes e a própria arquitetura. É o que Hertzberger (1996) chama de forma convidativa, a forma ou a arquitetura que acolhe as pessoas e promove a inter-relação entre elas e o meio. Analisando por este viés, é necessário que o espaço escolar, um dos primeiros espaços de socialização da criança, tenha essa forma convidativa e que se apresente como um espaço significativo e acolhedor, que atenue a ansiedade da separação da família e favoreça o sentimento de prazer de estar na escola.

Esse pensamento ressalta o significado do espaço enquanto lugar, aquele a que as pessoas atribuem valor e que só se torna concreto quando a relação delas com o espaço é plena e envolve todos os sentidos.

Essa ideia, verificada nos estudos de Tuan (1983) e de Frago e Escolano (2001), associa-se também ao conceito de ambiência, qualidade espacial que se configura como o conjunto de fatores necessários para tornar um ambiente agradável e protegido. Estes fatores podem ser relativos à cultura, envolvendo materiais, formas, cores e texturas do ambiente construído, e 
relativos ao conforto ambiental necessário à condição humana.

Neste sentido, se considerado como lugar e como um ambiente agradável e favorável à aprendizagem, o espaço destinado à educação infantil deve acolher, estimular e proporcionar a elas a oportunidade de brincar, crescer, inventar, ser, criar, explorar, enfim, oportunidades que talvez não encontrem em qualquer outro lugar.

Outros conceitos, como os de intimidade, privacidade e conforto, tão bem explanados nos estudos de Rybckzinsky (1986), se juntam aos aqui apresentados como valores importantes no estudo do espaço e que deverão ser considerados quando da elaboração de projetos que acolhem as crianças da educação infantil. No projeto da escola a ser desenvolvido, o acolhimento deverá ser verificado desde a implantação do edifício no terreno, no modo pelo qual formas, materiais, cores e texturas são combinados, a fim de se obter um espaço agradável e favorável à aprendizagem.

Projetar uma arquitetura escolar que valorize o ambiente de aprendizagem é uma atribuição complexa, que envolve várias áreas do conhecimento. Mesmo que as soluções sejam simples, requerem muito cuidado para que possam atender satisfatoriamente à sua finalidade.

Nair, Fielding e Lackney (2009, p. 18-19) lembram que estudar questões relativas ao espaço é importante porque ele lida com os quatro domínios da experiência humana: espacial, psicológico, fisiológico e comportamental. Cada um desses domínios possui atributos múltiplos que podem ser verificados na esfera do planejamento da arquitetura e design escolares:

1. Espacial: íntimo, aberto, iluminado, fechado, ativo, quieto, conectado com a natureza, tecnológico.

2. Psicológico: calmante, seguro, inspirador, alegre, divertido, estimulante, criativo, encorajador de reflexão, espiritualmente elevador, criador de senso de comunidade.

3. Fisiológico: quente, frio, aconchegante, ventilado, saudável, aromático, texturizado, visualmente agradável.

4. Comportamental: trabalho independente, trabalho colaborativo, trabalho em equipe, atividade fitness, 
1 Estes aspectos são aspectos positivos contrastantes e/ou complementares que são importantes para o projeto de escola que se pretende elaborar. pesquisa, escrita, leitura, trabalho no computador, canto, dança, performance, apresentação, trabaIho em grandes grupos, comungando com a natureza, projetando, ensinando, relaxando, construindo, brincando, refletindo.

Entretanto, estes atributos ${ }^{1}$ nunca aparecem isolados, eles se relacionam entre si e essas relações são sempre contextuais. O conhecimento deles deve ser considerado na elaboração de projetos arquitetônicos de escolas, pois, além da importância da proposta pedagógica, é o espaço e as possibilidades que ele oferece aos seus usuários para enriquecer esses quatro domínios de suas experiências que vão definir o que uma escola é.

O planejamento do edifício escolar não pode ser visto apenas do ponto de vista funcional/dimensional; é preciso compreender como seus usuários sentem e vivenciam seu espaço, para propor ambientes estimulantes e adequados aos vários tipos de aprendizagem. Neste sentido, verifica-se que a percepção tem papel fundamental na relação homem-ambiente, visto que qualquer ambiente só pode ser experimentado plenamente se forem envolvidos todos os sentidos. Os estudos de Hall (1989), Tuan (1983), Lynch (1997) e Rapoport (1978) demonstram este pensamento.

O planejamento do edifício escolar não pode ser visto apenas do ponto de vista funcional/dimensional; é preciso compreender como seus usuários sentem e vivenciam seu espaço, para propor ambientes estimulantes e adequados aos vários tipos de aprendizagem.

Neste sentido, verifica-se que a percepção tem papel fundamental na relação homem-ambiente, visto que qualquer ambiente só pode ser experimentado plenamente se forem envolvidos todos os sentidos. Os estudos de Hall (1989), Tuan (1983), Lynch (1997) e Rapoport (1978) demonstram este pensamento.

Nos estudos de Rapoport (1978), verifica-se que o termo percepção se explica pelas ações integradas da avaliação, cognição e percepção, essas três consideradas como fases consecutivas de um mesmo processo de construção do meio percebido, sendo a percepção referente aos sentidos e a cognição envolvendo experiência, conhecimento e memória. Segundo este autor, a percepção enriquece a experiência e a cognição clarifica e simplifica o meio; quando o objetivo vai além do conhecimento cognitivo do meio, e a experiência perceptual é desejável, chega-se à complexidade. 
A complexidade não só relaciona a cognição e a percepção, mas apresenta-se como um nível ideal, entre o caos e a monotonia. Os meio ambientes perceptivamente mais ricos e complexos são sempre os preferidos. Para se evitar a monotonia, Rapoport (1978) sugere que os espaços propiciem mistura de usos, manipulação de itinerários, estabeleçam relações entre várias áreas, ofereçam opções de desenho aberto e com influência do meio natural.

Lynch (1997) também considera que a percepção através dos sentidos e outros indicadores sensoriais como: sensações visuais de cor, forma, movimento, luz, cinestesia, sentido de gravidade, ajudam na estruturação e identificação dos ambientes.

De sua pesquisa ressaltam-se os conceitos de imaginabilidade e legibilidade ou visibilidade e ainda os aspectos que o autor aponta como importantes para o design urbano: singularidade, simplicidade de forma, continuidade, predominância, clareza de ligação, diferenciação direcional, alcance visual, consciência do movimento, séries temporais, nomes e significados.

Para Rapoport (1978), a legibilidade não deve se contrapor à complexidade, antes, deve complementá-la, já que o desejável é conseguir clareza na macroescala e complexidade na microescala.

Existem outros fatores subjetivos ligados à complexidade. Mazzilli (2003) lembra que, assim como na música, a qualidade emocional é dada pelo músico e não apenas por sua estrutura (tom, ritmo e harmonia), há elementos que vão além da consciência: contraste de elementos com relação a um fundo, novidade, surpresa, mistério, variações no tempo, simbolismo e significado. A quantidade e o caráter desses elementos, e a forma como eles se relacionam podem produzir interpretações distintas intensificando os sentidos.

$\mathrm{Na}$ arquitetura, a complexidade pode ser refletida na riqueza de ambientes com texturas e cores variadas, não visíveis de um único ponto de vista, com seus mistérios e surpresas. Essas características podem ser consideradas elementos lúdicos, que enriquecem a percepção espacial e, consequentemente, a aprendizagem.

No projeto proposto neste trabalho, a complexidade deverá ser avaliada, de forma geral, no modo pelo qual as formas se articulam para:

- criar um desenho aberto, com diversas possibilidades de fluxos e caminhos; 
- respeitar a topografia do local e a vegetação existente;

- favorecer a manipulação do espaço, possibilitando mistura de usos nos ambientes da escola;

- interagir com o meio natural;

- integrar-se à comunidade;

- obter uma qualidade espacial, na qual a própria arquitetura da escola se torna um elemento significativo local.

\section{Polivalência}

As discussões apresentadas anteriormente sugerem que, para o planejamento de espaços para a educação infantil, é necessário pesquisar os mecanismos perceptivos e cognitivos aos quais a criança recorre para reconhecer seu espaço; quando a criança puder dominar este espaço, conhecendo e visualizando a área destinada a ela, sua experiência espacial será mais rica.

É importante atentar para a necessidade de oferecer à criança espaços que tenham a capacidade de provocar reações específicas, adequadas a situações específicas. Os espaços não devem ser neutros, mas devem conter uma variedade de proposições e estímulos que sejam capazes de despertar associações, ou seja, devem ter uma maior eficácia, aquela que Hertzberger (1996) chama de polivalência.

Quando Hertzberger (1996) fala de polivalência, fala de espaços que têm suas possibilidades de uso expandidas, um potencial maior de acomodação, que poderá torná-los mais receptivos a diferentes situações e que, consequentemente, tenham mais a oferecer. Para ele, os espaços devem ser perceptíveis e articulados para criarem lugares, ou seja, unidades espaciais cujas dimensões permitam acomodar os tipos de relações e atividades das pessoas que irão utilizá-los.

Hertzberger associa a qualidade de lugar à capacidade variável de um espaço de ser convidativo para distintos grupos, dependendo de suas dimensões e forma. Esta qualidade parece estar relacionada ao equilíbrio entre abertura e fechamento, intimidade e exterioridade, que assegura polos de encontro onde as pessoas se relacionam e compreendem que estão juntas ocupando um todo espacial. 
Na qualidade de lugar onde crianças e adultos se reúnem, o espaço escolar deve ser organizado de tal forma que ofereça oportunidades para que o processo de ensino-aprendizagem se desenvolva em ambientes articulados corretamente, em outras palavras, em ambientes dimensionados e adaptados ao padrão de relações necessário entre os usuários e o edifício.

Percebe-se, desta forma, que polivalência e complexidade se inter-relacionam quando se quer propor espaços interessantes e convidativos, espaços que interagem positivamente com seus usuários.

Para o projeto de escola de educação infantil, a polivalência deverá ser verificada na:

- articulação das formas, especialmente das salas de atividades, facilitando a estruturação dos ambientes em áreas (jogos e brincadeiras, contação de histórias, exposição de trabalhos, etc.);

- organização flexível dos ambientes, permitindo a transformação do espaço de acordo com a necessidade e para acomodar uma variedade de modalidades de aprendizagens;

- flexibilidade, adaptabilidade e variedade de elementos;

- diversidade de espaços oferecidos para as diferentes aprendizagens;

- variedade de elementos articuladores, tais como: palcos, tanques de areia, pérgulas, painéis de exposição, espelhos d'água e duchas, incentivos que favorecem o uso e a apropriação dos espaços onde estão inseridos.

\section{Transparência}

A transparência é um conceito importante para projetos de escolas, tanto na esfera da educação quanto na esfera da arquitetura. Escolas transparentes transmitem a ideia de que a aprendizagem deve ser visível, estimulada e celebrada. Isto se torna possível quando o processo de ensino-aprendizagem acontece em espaços que viabilizam esta intenção.

Compreendendo a importância da dimensão espacial para o desenvolvimento infantil, algumas ideias relevantes no estudo do espaço e na relação criança/ambiente, podem ser reunidos nesta mesma abordagem. Nos estudos de Coelho Neto (1979) vê-se materiali- 
2 Estudo do que é percebido pelos sentidos e pela consciência. A fenomenologia trata de descrever, compreender e interpretar os fenômenos que se apresentam à percepção.

3 KOROSEC-SERFATY, P. Experience and Use of the Dwelling. In: ALTMAN; WERNER, C. M. (Ed.). Home Environments. New York: Plenum Press, 1985. p. 65-83. zada, através dos sete eixos que ele propõe - espaço interior $x$ espaço exterior, espaço privado x espaço comum, espaço construído $x$ espaço não construído, espaço artificial $x$ espaço natural, espaço amplo x espaço restrito, espaço vertical $x$ espaço horizontal, espaço geométrico $x$ espaço não geométrico -, a definição e organização do sentido do espaço na arquitetura, considerações fundamentais não só para o projeto da escola que ora se propõe, como para qualquer projeto de arquitetura em que o interesse está focado nas pessoas e na relação entre elas e o meio.

Na pesquisa de Elali (2002), destaca-se a relevância de conceitos como: espaço-pessoal, distâncias interpessoais, territorialidade, aglomeração, privacidade, lugar, adaptação e apropriação, pois ajudam a esclarecer as relações que envolvem as pessoas com o ambiente.

Partindo desses estudos e procurando estabelecer uma relação entre eles e o conceito de transparência, chega-se a algumas noções da fenomenologia ${ }^{2}$.

Os fenômenos humanos estão relacionados com as dimensões fenomenológicas e com os elementos que eles representam na arquitetura. Eles são expressos por fatores comportamentais como territorialidade, privacidade, identidade e ambiência. As dimensões fenomenológicas são relações que buscam explicar como os usuários interagem com o espaço.

Como aponta Malard (2001), segundo a classificação de Korosec-Serfaty (1985) ${ }^{3}$, as dimensões fenomenológicas fundamentais do morar podem ser definidas nas seguintes relações:

- estabelecimento de um interior/exterior

- estabelecimento de visibilidade

- apropriação

Todo ambiente construído está submetido ao estabelecimento da dialética interior/exterior, ou seja, está sujeito à definição de lugares que podem se tornar universos particulares. Desta dimensão emerge a questão da visibilidade, onde aberturas, portas e janelas atuam como elementos articuladores entre espaços internos e externos, tornando-os visíveis ou escondidos. A apropriação revela o modo de experimentar o ambiente.

Neste sentido, o conceito de transparência se relaciona a essas dimensões, e é fundamental para se desen- 
volver uma escola com altos níveis de conectividade entre espaços internos e externos, abertos e fechados, e de visibilidade em todas as áreas de aprendizagens. A configuração dos espaços, com grandes portas e janelas de vidro, voltadas para jardins, pátios internos e externos e ampla vegetação, cria a sensação de abertura, aumenta a iluminação natural, facilita a supervisão passiva ${ }^{4}$ dos professores. Além disso, a transparência também contribui com a segurança, uma vez que a visibilidade possibilita o conceito de "olhos na rua", o qual associa diretamente a vigilância natural com a segurança dos espaços públicos e privados (JACOBS, 2000).

Relaciona-se ainda o conceito de transparência ao sentido educador da arquitetura, ressaltado por Frago e Escolano (2001). Esses autores qualificam o espaço escolar como um espaço cultural que, dotado de significados, transmite grande quantidade de estímulos às crianças, considerando-o, portanto, como um elemento eficaz de educação. Na configuração de ambientes escolares, a arquitetura sustentável também pode ser uma aliada do processo de ensino-aprendizagem, especialmente quando os sistemas da construção são visíveis. Ela pode se tornar um modelo dinâmico para ensinar noções de arquitetura, engenharia, construção e ciência ambiental, em harmonia com a natureza.

Para o projeto que se propõe neste estudo, a transparência deverá ser aferida pela:

- utilização de amplas portas e janelas de vidros em todos os espaços, para criar o sentimento acolhedor e permitir à equipe pedagógica o monitoramento das crianças em suas atividades na escola;

- acesso visível da área da recepção para as várias áreas de atividades das crianças, para transmitir à comunidade o propósito da escola;

- forte relação de visibilidade entre as salas de atividades e as áreas de aprendizagem informal; isto facilita a supervisão passiva dos professores;

- articulação dos planos de telhado, permitindo que a luz natural penetre nos ambientes de passagem, reduzindo desta forma o sentimento de fechamento e insegurança, causado por ambientes escuros;

- articulação dos espaços, criando vistas interessantes de diferentes partes da escola, para criar sensação de surpresa à medida que as pessoas se movem dentro do edifício;
4 o conceito de supervisão passiva está relacionado à facilidade de monitoramento da equipe de professores e técnicos, no cuidado com as crianças 
- acessibilidade direta entre áreas internas e externas e facilidade de supervisão passiva, trazendo mais luz natural e encorajando professores e crianças a usarem os espaços externos para outras aprendizagens;

- utilização de portas acústicas opacas deslizantes entre as salas de atividades, permitindo o funcionamento independente das salas e, em ocasiões especiais, o funcionamento conjunto;

- possibilidade de expansão dos horizontes das crianças, criando linhas de visibilidade que se estendem o máximo possível para fora das salas de atividades, permitindo contato com a natureza;

- quantidade de luz natural oferecida aos usuários da escola combinada com dispositivos de sombreamento, árvores e outras vegetações estrategicamente localizadas;

- utilização de sistemas naturais para aquecimento e reaproveitamento da água, valiosos pela sua afabilidade ambiental e o grande potencial para ensinar a respeito de conservação e utilização de energia;

- $\quad$ exposição de elementos estruturais do edifício.

\section{Ludicidade}

Considerando a relevância da atividade lúdica como fator importantíssimo para o desenvolvimento das crianças, relacionam-se aspectos e conceitos ligados ao lúdico que se associam ao caráter de jogo, brincadeira e divertimento. A atividade lúdica assim representada não só colabora para este desenvolvimento como é ferramenta valiosa no processo de aprendizagem infantil.

Conforme o pensamento de Brougère (1998), o lúdico (como jogo) pressupõe uma aprendizagem social, que resulta da interação entre as pessoas e supõe regras que favorecem o exercício, o faz de conta, o imaginário e a invenção. O autor considera que o jogo é lugar de inovação e exploração e que a cultura lúdica é rica, complexa e diversificada.

Na escola, o jogo traz benefícios a todas as crianças, tornando divertido e alegre o processo de ensino -aprendizagem. Sua utilização não objetiva apenas a diversão e o entretenimento, mas aprendizagens que desenvolvem a criatividade, a socialização, o raciocínio 
e a coordenação motora, enfim, que desenvolvem os domínios cognitivo, afetivo e psicomotor das crianças.

Segundo Piaget (1972), quando as crianças brincam, elas estão se socializando e desenvolvendo suas percepções, inteligências e tendências à experimentação. Neste processo, o desenvolvimento cognitivo das crianças pode ser afetado pela interação delas com o espaço, relacionando desta forma a capacidade de aprendizado não apenas à atividade lúdica, mas também à percepção espacial.

Neste sentido, Lima (1995) considera o espaço fundamental, pois é nele e através dele que é possível a realização de atividades lúdicas, tão importantes na aprendizagem e desenvolvimento infantil. A autora afirma que o espaço escolar deve ser um lugar para brincar, crescer e se desenvolver.

Desta forma, é importante que a ludicidade seja desenvolvida em todos os espaços da escola, não somente nas áreas externas, mas no aprendizado integrado às outras disciplinas, pois facilita a participação das crianças nas atividades pedagógicas e ajuda no desenvolvimento de suas inteligências múltiplas. É necessário, portanto, uma relação positiva entre ludicidade, qualidade espacial e desenvolvimento intelectual.

A teoria das inteligências múltiplas de Howard Gardners (apud Nair, Fielding, Lackney, 2009), diz que todos os seres humanos têm oito inteligências: linguística, lógico-matemática, musical, cinestésico-corporal, espacial, naturalista, interpessoal e intrapessoal.

Ainda que esta teoria esteja relacionada com estudos da mente, e não como estratégia de intervenção educacional, Nair, Fielding e Lackney (2009) consideraram importante entender e aplicar esta teoria no planejamento de ambientes escolares.

Nair, Fielding e Lackney (2009) estabelecem uma relação entre essas inteligências múltiplas e os tipos de espaços escolares. Afirmam que, para se criar ambientes de aprendizagem interessantes e interativos, é necessário que eles acomodem o máximo possível dessas inteligências. Para eles, determinadas configurações espaciais, tais como: anfiteatro, biblioteca, terraços, praças e salas com possibilidades de expansão ou com mobiliário agrupado em divisórias, são superiores, do ponto de vista desta teoria, a uma sala de aula tradicional, pois conseguem nutrir, no mesmo espaço, várias inteligências. 
Esses autores consideram que certos ambientes levam as crianças a distintos comportamentos físicos e sociais. Embasados em diferentes pesquisas, afirmam, por exemplo, que tetos altos como os de um ginásio encorajam o comportamento ativo; tetos baixos, o comportamento quieto; espaços maiores e mais abertos levam as crianças a demonstrar sentimento de exploração sensorial e tátil, possibilitam maior interação e oportunidades para a autonomia, mas fornecem menos oportunidades para o comprometimento cognitivo.

Neste sentido, percebe-se que nas escolas de educação infantil essa teoria poderá ser aplicada com a utilização de atividades lúdicas integradas aos vários tipos de aprendizagens, e realizadas em espaços que permitam que elas se realizem. Por exemplo: uma criança que tenha dificuldade de aprender determinado assunto numa configuração de sala de aula tradicional, usando sua inteligência cognitiva, poderá aprender este mesmo assunto no pátio descoberto da escola, ou em outro ambiente, através de brincadeiras ou performance, utilizando sua inteligência cinestésicocorporal ou musical. A ludicidade, aliada à qualidade do espaço, pode estimular a inteligência da criança. Sendo assim, tanto a ludicidade quanto as qualidades espaciais aqui colocadas, e representadas pelo acoIhimento, polivalência, complexidade e transparência, conferem aos espaços a dimensão lúdica que se quer enfatizar, ou seja, aquelas qualidades que os tornam mais atraentes, interativos e estimulantes para a criança.

No projeto de escola proposto, a ludicidade deverá ser verificada, de forma geral, no modo pelo qual os espaços internos e externos interagem para promover a socialização das crianças e o surgimento de situações e atividades lúdicas. Mais especificamente:

- na configuração ampla e com pés-direitos altos das salas de atividades;

- nos terraços de aprendizagens externos, integrados às salas de atividades;

- no favorecimento da autonomia e segurança da criança, através de mobiliário e materiais acessíveis que garantam a ausência de riscos;

- na diversidade e complexidade das áreas externas (presença de árvores, desníveis no terreno, escadas, rampas, nichos, brinquedos, horta, pomar, terraços para atividades "sujas"), estimulando o 
livre brincar e o senso de aventura e de exploração da criança;

- nos locais para performances teatrais, faz de conta, dança, música, tais como: anfiteatro e pátios integrados às áreas comuns das salas;

- nos amplos eixos de circulação, que transformam simples percursos em divertidos passeios e aprendizagens;

- na presença de elementos essencialmente lúdicos, tais como: pérgulas, espelhos d'água, duchas, parques de areia, parques com brinquedos e casa de bonecas;

- nos cantos e recantos;

- no uso de texturas e cores variadas e de materiais perceptíveis.

\section{Diretrizes projetuais}

O processo de projeto iniciou-se com os estudos teóricos e desenvolveu-se após a verificação da legislação pertinente às escolas de educação infantil e a análise do programa de necessidades, das características climáticas da região e do sítio e, ainda, da consideração da hipótese de que de que a dimensão lúdica dos espaços escolares - aquelas qualidades que os tornam mais interativos, atraentes, estimulantes e acolhedores - contribui para um ambiente que promove a relação entre seus usuários, corresponde às necessidades da criança, participa e interage com a construção de seu conhecimento.

Essa hipótese conduziu a reflexão para alguns fatores que pudessem agir como catalisadores na interpretação dos dados obtidos inicialmente, fugindo, desta forma, de soluções previsíveis que serviriam somente para a satisfação óbvia das necessidades do programa para uma escola de educação infantil.

- Assim, desde o princípio, foram considerados importantes os seguintes fatores:

- valorização da esquina, estabelecendo um diálogo entre o edifício e o entorno;

- utilização de uma tipologia que configurasse uma "praça", ponto de encontro e socialização de seus usuários, onde o caráter lúdico do espaço pode ser revelado; 
- respeito às características originais e preservação de árvores existentes, elementos de grande importância para a arquitetura e para o microclima da região.

A partir daí o processo de projeto foi naturalmente se desenvolvendo com a alimentação constante das ideias discutidas na pesquisa, as quais determinaram uma ideia central, calcada nos conceitos de acolhimento, complexidade, polivalência, transparência e ludicidade, apresentados anteriormente.

Estes conceitos determinaram a essência do projeto, que pode ser revelada pelas seguintes diretrizes projetuais: integração com a comunidade; desenho aberto/interação com o meio natural; escola como uma pequena comunidade de aprendizagem; iluminação natural e ventilação natural; ambientes acolhedores; circulação como um passeio de aprendizagem; adaptabilidade/flexibilidade/variedade; transparência e supervisão passiva; arquitetura que ensina/sustentabilidade; espaços externos e incentivos lúdicos; materiais, texturas e cores como elementos de identidade.

Cumpre ressaltar que o ato de projetar não é um processo linear que se desenvolve a partir de um conceito até chegar a uma solução final. Projetos (desenhos) também podem levar a formulação de conceitos (ideias) e vice-versa. Existe uma relação mútua entre eles, onde todos os aspectos devem ser analisados e ajustados a fim de se chegar a uma solução que satisfaça todos os requisitos exigidos e todas as expectativas.

Apresenta-se a seguir o projeto (Figura 01, Figura 02, Figura 03), e um memorial justificativo das decisões tomadas segundo as diretrizes projetuais estabelecidas e anunciadas anteriormente.

\section{Integração na comunidade}

Um dos fatores que conferem significado à escola é a localização de seu edifício no tecido urbano. Se instalada no centro da comunidade, a escola pode exercer uma influência positiva na vida da população local. Assim, para a elaboração do projeto proposto nesta pesquisa, foi escolhido um sítio inserido no centro de uma área residencial. Esta situação facilita a implantação do edifício em lugar facilmente acessível pelas crianças e pessoas da comunidade circunvizinha, tanto para pedestres e ciclistas como para aqueles que chegam de carro ou ônibus. 

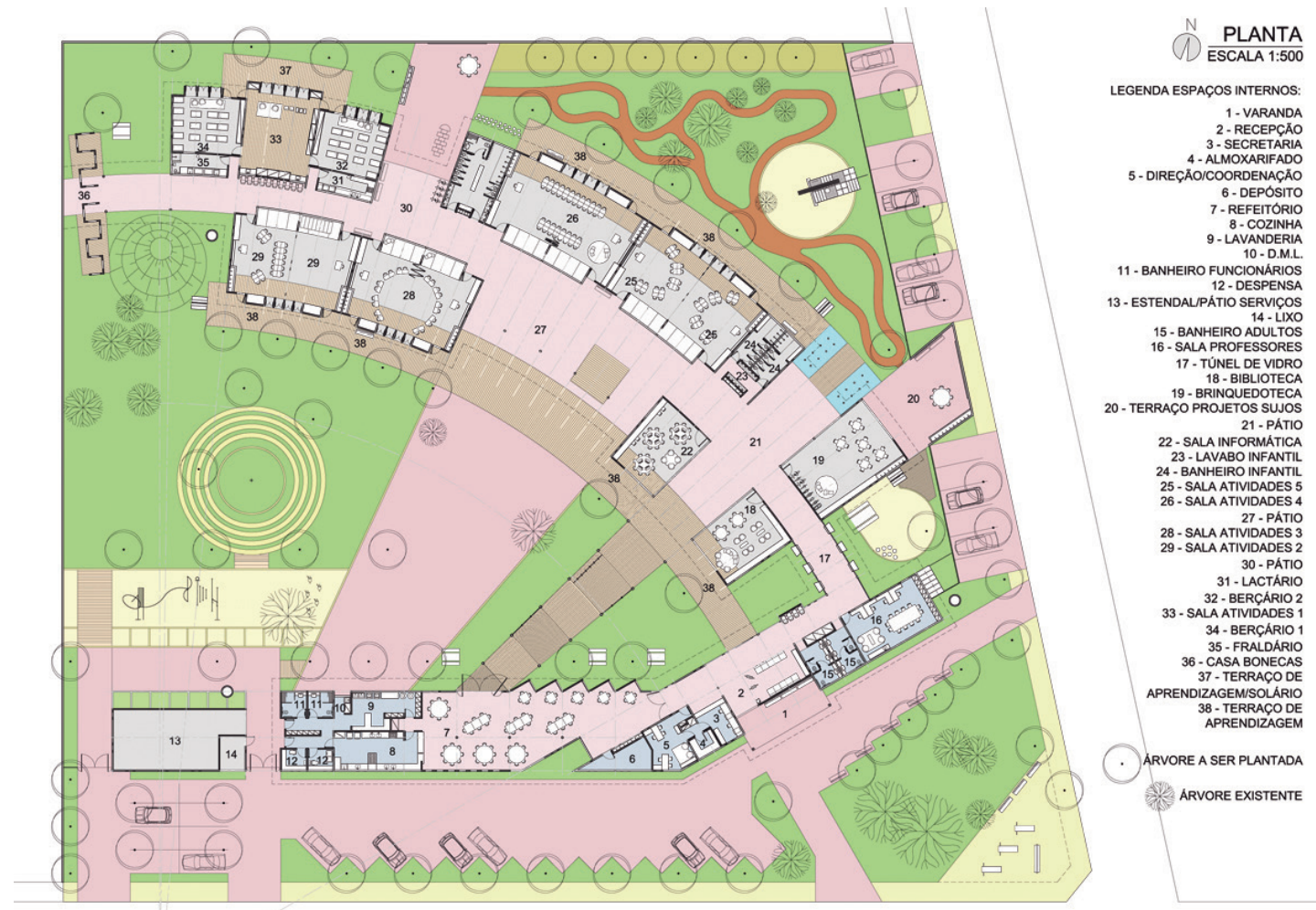

Figura 1

Layout espaços internos

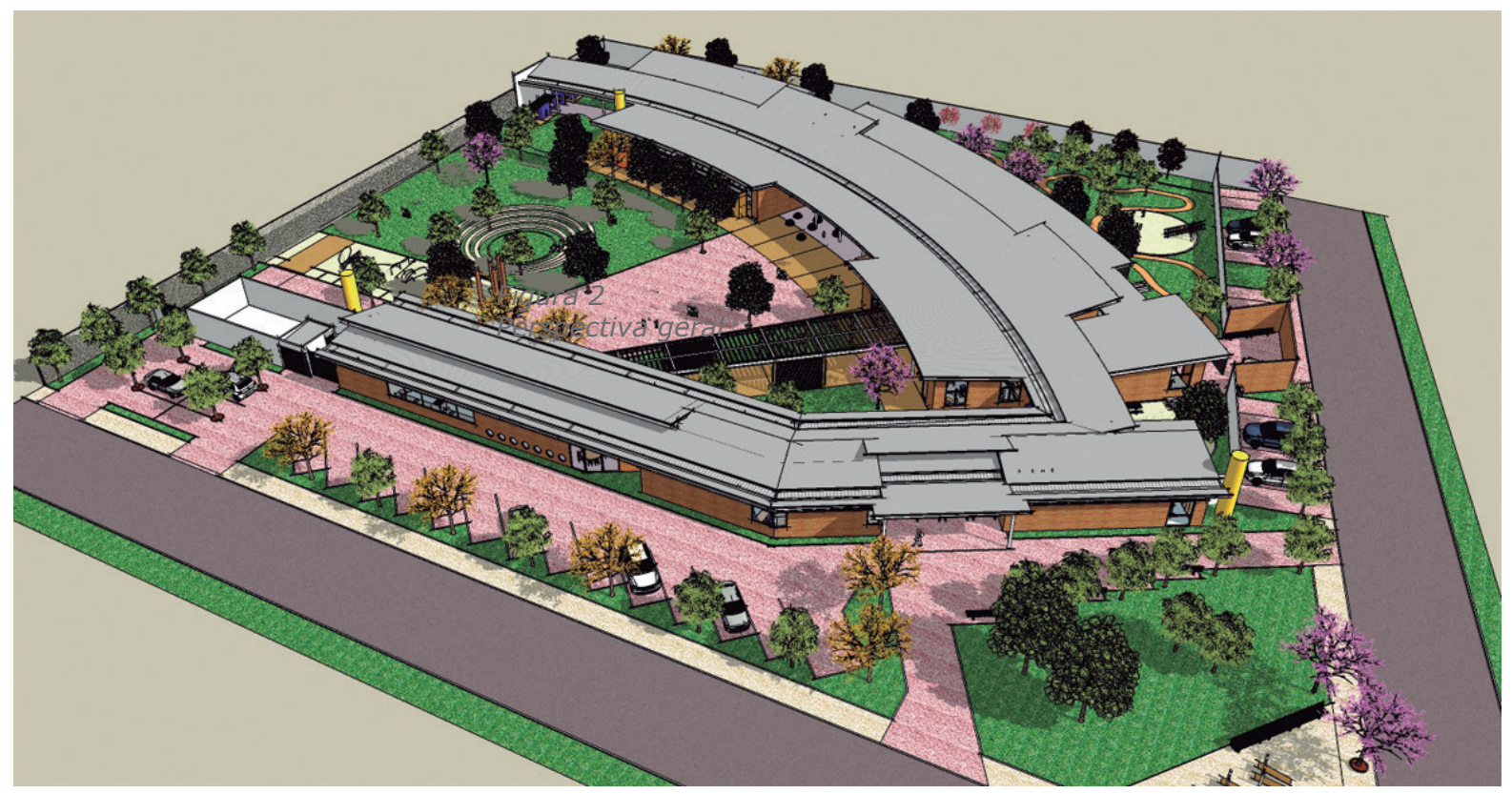

Figura 2

Perspectiva geral 

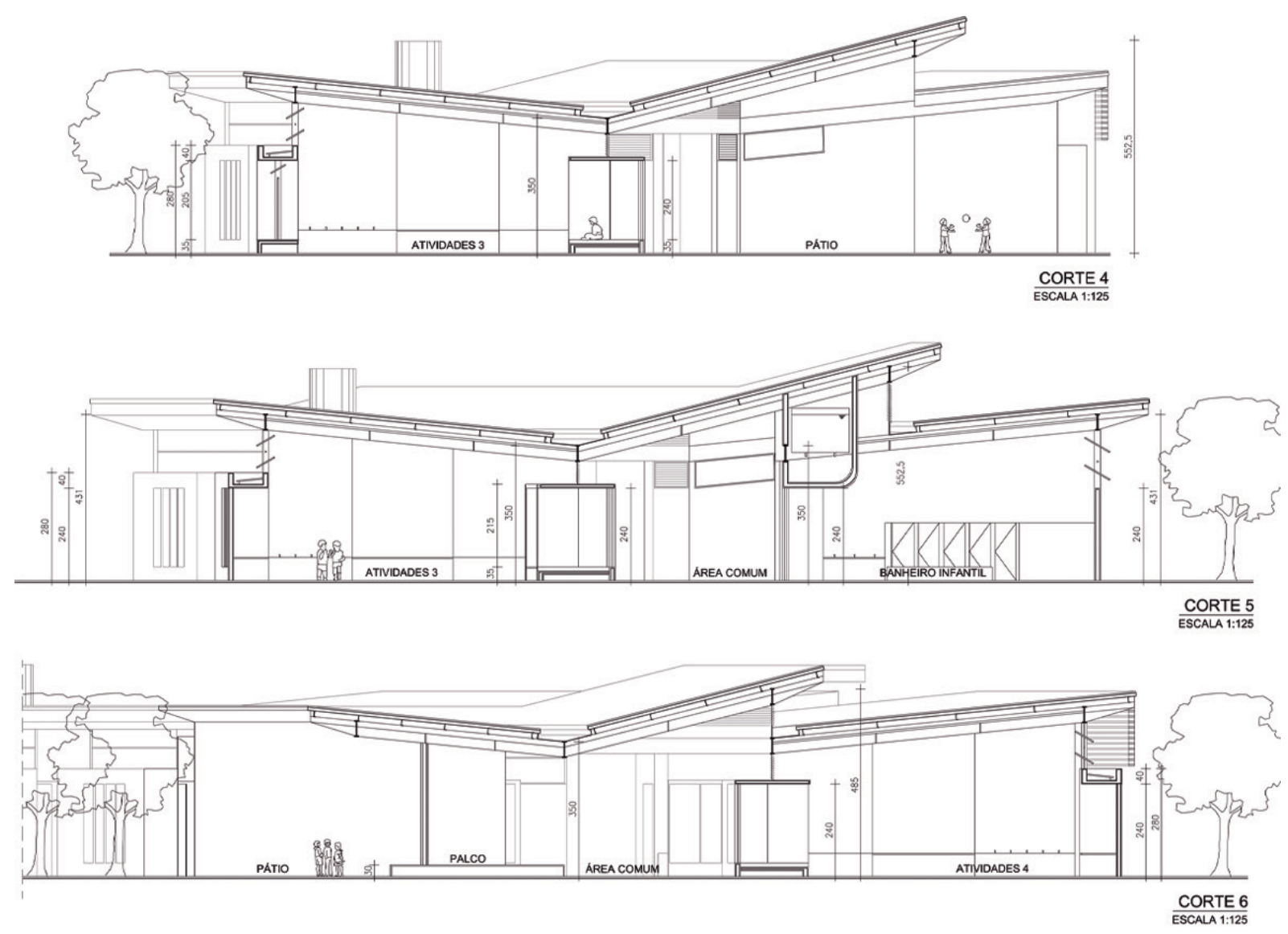

Figura 3

Segundo Nair, Fielding e Lackney (2009), escolas cujo foco principal é a aprendizagem devem direcionar-se para o lado de fora e a comunidade, para dentro (Figura 04). Isto significa criar redes de relacionamento interligados, em que a comunidade pode enriquecer a escola pelos serviços oferecidos por outros equipamentos urbanos locais, como hospitais, clubes, bibliotecas públicas, parques, etc., e em contrapartida a escola pode abrir suas portas até à noite para atividades de programas de educação adulta e atividades sociais e de recreação, como música, dança e teatro. Neste projeto, essa ideia foi contemplada na maneira como a própria escola foi projetada: para ser um elemento significativo local e um lugar acolhedor para as crianças e para a comunidade.

\section{Desenho aberto/integração com o meio natural}

Há um crescente número de estudos que correlatam a saúde e o bem-estar das pessoas com o tempo/espaço em que elas ficam em contato com a natureza. Pesquisas comprovam que aberturas e janelas voltadas para espaços externos com presença de vegetação e água produzem efeitos positivos no comportamento 
das pessoas e que podem se refletir num estado de ânimo relaxado, com menor tensão muscular e pressão sanguínea.

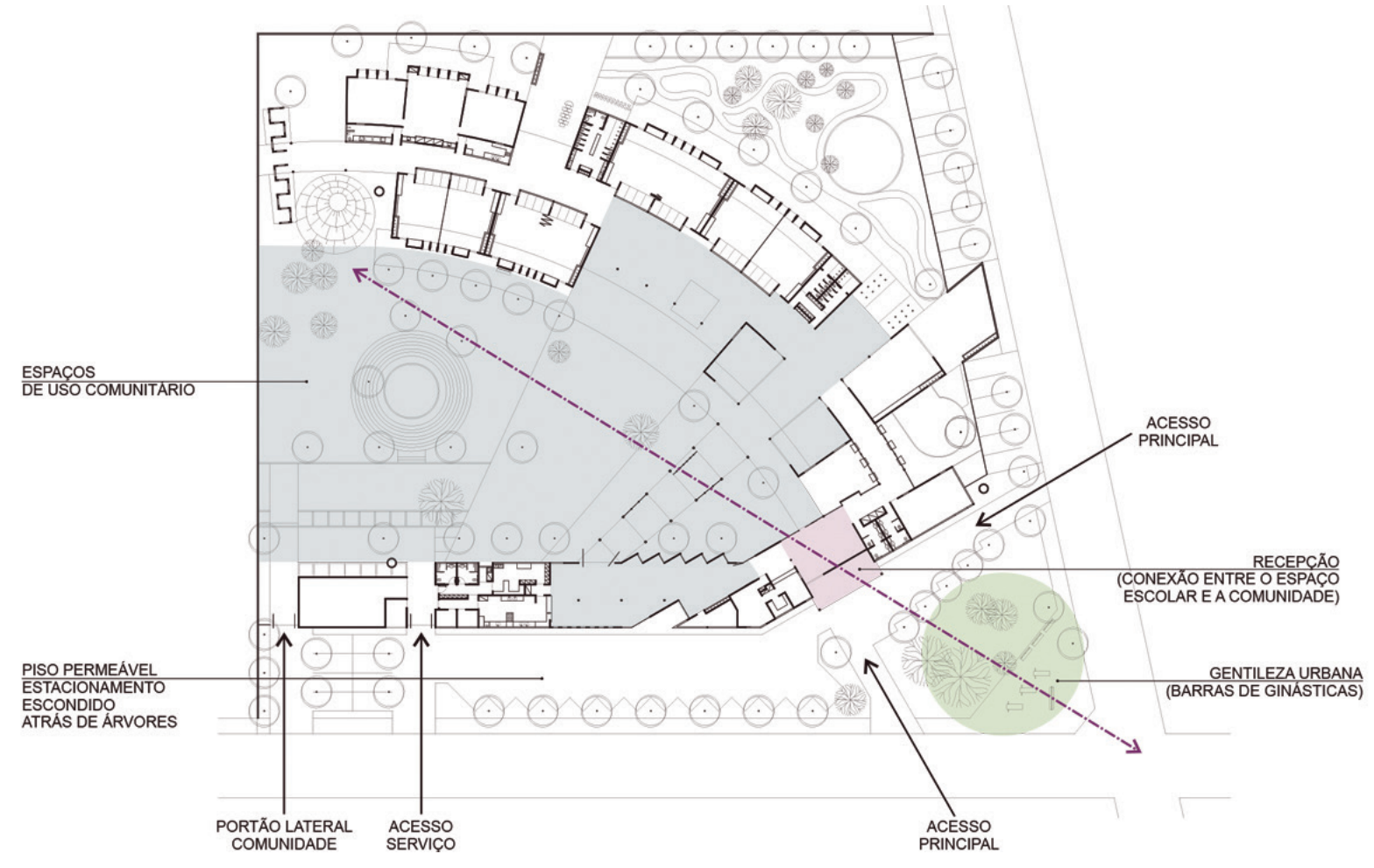

Figura 4

Tipologia tipo "praça" favorece o encontro e a socialização dos usuários

Dado que a maioria das atividades humanas, e aí se inclui a maior parte das aprendizagens, se desenvolve em ambientes fechados, existe grande benefício em expandir os horizontes, especialmente os da educação infantil, para criar linhas de visibilidade que se estendem o máximo possível para fora desses ambientes. Para este projeto, a ideia foi criar um desenho aberto, com espaços articulados e integrados ao meio natural. Essa configuração permite maior possibilidade de fluxos e variedade de caminhos, facilitando, desta forma, o acesso aos ambientes e a mobilidade espacial; permite também que o exterior se torne uma extensão natural das aprendizagens que acontecem no interior, uma arena para vários tipos de projetos (Figura 05).

Assim, o edifício foi implantado de modo a respeitar as características do terreno, estabelecendo a relação interior/exterior através de espaços abertos e fluidos, configurados para acomodar a realização das diversas atividades pertinentes à educação infantil. 


\section{A escola como uma pequena comunidade de aprendizagem}

A proposta que norteou o projeto desta escola foi a de criar uma pequena comunidade de aprendizagem para aproximadamente 180 crianças, na qual os espaços estão qualificados para oferecer ambientes propícios ao desenvolvimento infantil, e cujo foco está voltado para a aprendizagem lúdica.

Esta proposta se diferencia das propostas de escolas tradicionais, cuja filosofia educacional, baseada na sala de aula, tem como pressuposto que todos os estudantes são como vasos vazios a serem enchidos com o conhecimento, e que todos irão aprender a mesma coisa, ao mesmo tempo, com o mesmo professor, do mesmo modo e no mesmo lugar, durante várias horas do dia.

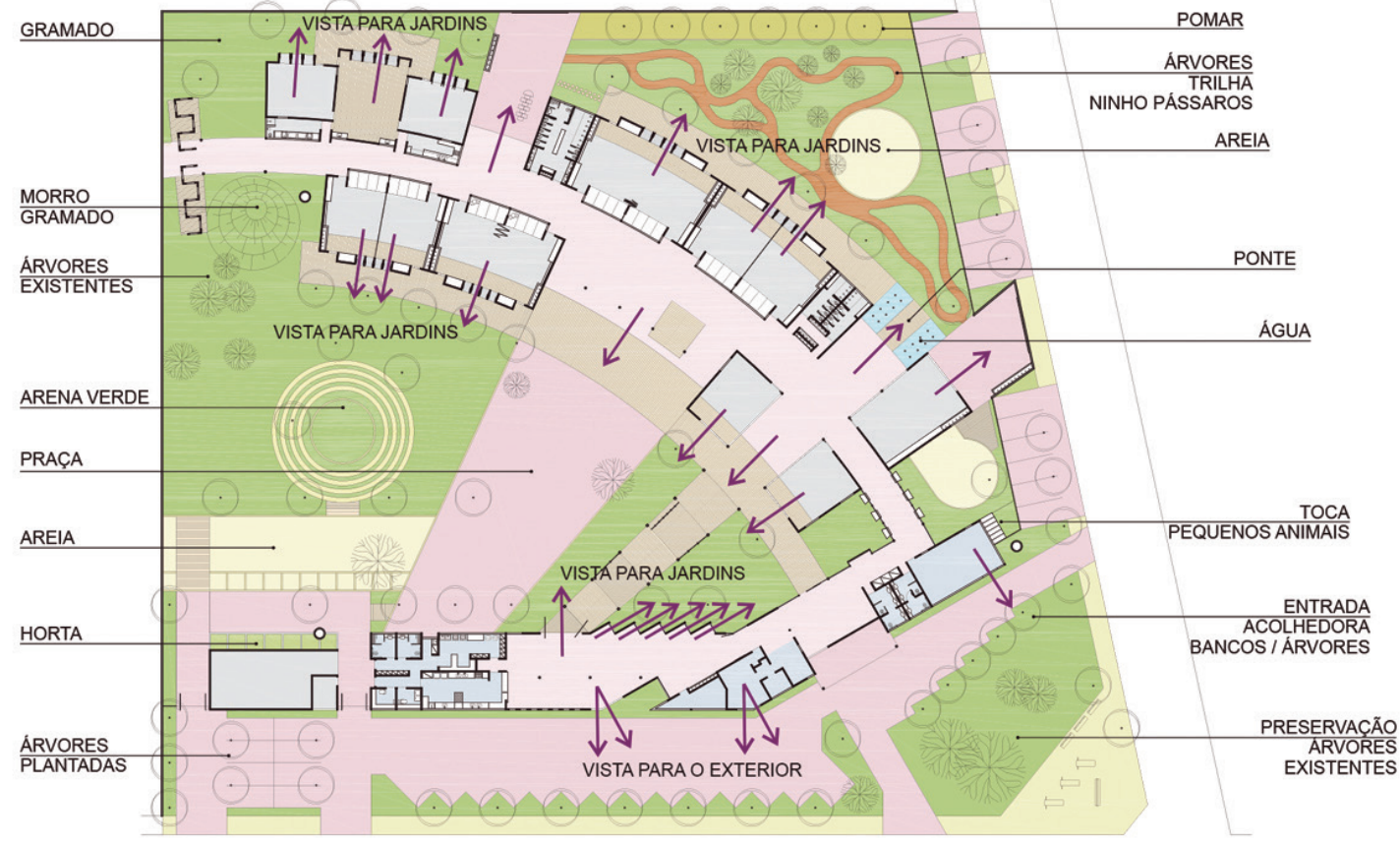

Figura 5

Ambientes internos conectados aos ambientes externos

A expressão vasos vazios traz à memória o empirismo de John Locke (1632 - 1704), que relacionou a mente humana a uma "tábula rasa" (folha em branco), sugerindo que as pessoas nascem sem conhecimento algum e 0 adquirem a partir das experiências. Embora o conceito de "tábula rasa" já tenha sido superado, o empirismo de Locke é relevante, pois se contrapõe ao modelo de construção do conhecimento das escolas tradicionais. 
Segundo Nair, Fielding e Lackney (2009) esse modelo educacional tradicional faz sentido para escolas com salas agrupadas ao longo de um corredor de dois lados, onde cada sala possui cerca de 25 a 30 cadeiras com braço para os alunos e uma mesa para o professor, colocada na frente da sala; e ainda, se para melhorar o controle, as aulas forem anunciadas por sinos a cada 45 minutos, após os quais uma atividade termina para dar início a outra.

Este modelo de células e sinos, conhecido como modelo Ford, é ultrapassado, especialmente quando a proposta pedagógica da escola está focada em uma instrução diferenciada e cujos espaços, devem acomodar várias modalidades de aprendizagens: estudo independente; tutoria; estudo em equipe; aprendizagem individual com professor; formato leitura direcionada pelo professor; aprendizagem baseada em projetos; tecnologia com computadores móveis; aprendizagem à distância; pesquisa baseada na internet; apresentação dos estudantes; aprendizagem baseada em performance; instrução estilo seminário; aprendizagem interdisciplinar; aprendizagem naturalista; aprendizagem social, emocional, espiritual; aprendizagem baseada na arte; contação de histórias; aprendizagem baseada no desenho; aprendizagem baseada no ensino em equipe; aprendizagem baseada em jogos.

Para Nair, Fielding e Lackney (2009), as razões para se romper com o modelo Ford podem ser justificadas em diversas pesquisas que demonstram que a aprendizagem não acontece de maneira linear, mas de uma forma holística e multifacetada. Essas pesquisas partem da ideia de que os estudantes podem aprender coisas diferentes, com pessoas diferentes, em lugares diferentes, de modos diferentes e em tempos diferentes.

Diante deste novo paradigma, é importante que os espaços escolares sejam reciclados e/ou planejados e adequados a esta necessidade. No caso de escolas de educação infantil, é importante oferecer uma diversidade de espaços que acomodem as várias modalidades de aprendizagens, especialmente a aprendizagem baseada em jogos, ou seja, a aprendizagem lúdica.

Neste sentido, propôs-se para esta escola uma pequena comunidade de aprendizagem. Essa pequena comunidade, que se confunde com a própria escola, deverá suprir pelo menos $60 \%$ das necessidades das crianças no seu processo de desenvolvimento e aprendizagem. 
O programa da escola comporta:

- entrada convidativa articulada a ambientes internos;

- ambientes administrativos e sala de professores com vista para o exterior e para ambientes internos da escola;

- salas de atividades combinadas duas a duas e separadas por painéis acústicos deslizantes, alinhadas ao longo de uma circulação ampla e aberta;

- sala de atividades para bebês e berçários conjugados, conectados ao fraldário e lactário;

- salas especiais;

- refeitório amplo com conexão para o exterior (Figura 06);

- banheiros infantil e adulto;

- circulação ampla e aberta configurada como um espaço social;

- terraços para aprendizagens externas;

- praça central e espaços externos;

- painéis de exposição dos trabalhos das crianças;

- mobiliário adequado e acessível pelas crianças;
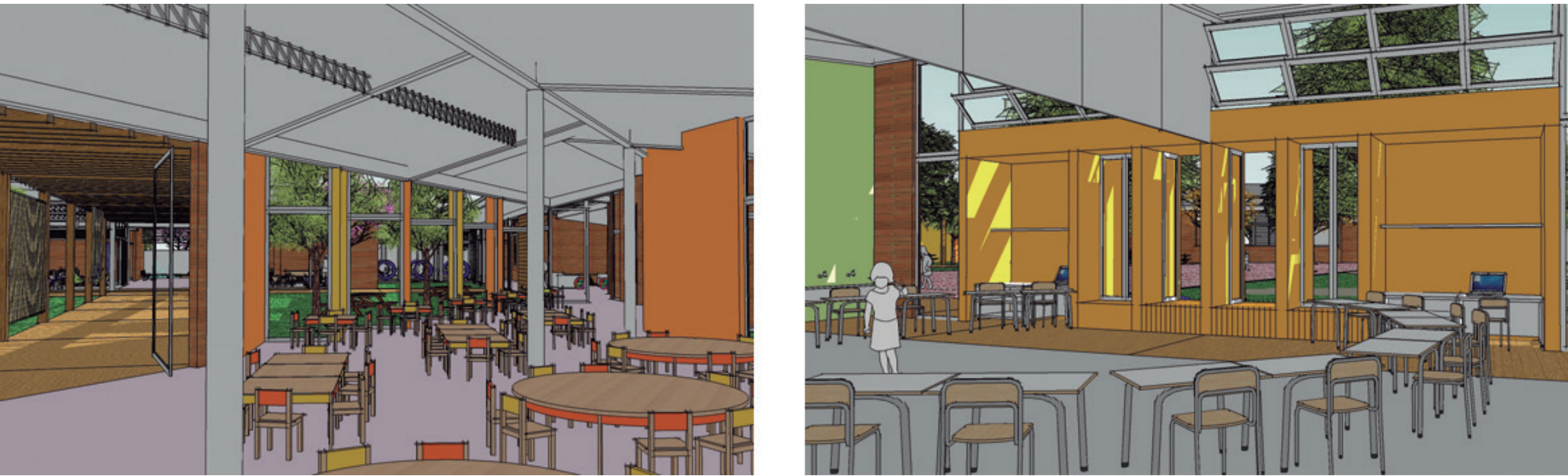

Figura 6

Vista do refeitório e das salas de atividades 
- cozinha e espaços de serviço.

Complementam esta configuração os espaços externos periféricos (jardins, trilhas, gramados com árvores, outros parques de areia com brinquedos, espelho d'água, duchas, horta, etc.), que se oferecem como lugares especiais para suporte de outras tantas atividades, estabelecendo uma tipologia em que a aprendizagem lúdica é uma das peças essenciais do projeto.

\section{Iluminação natural e ventilação natural}

A iluminação natural é um dos fatores essenciais para o bom planejamento de ambientes escolares, pois está diretamente relacionada com a qualidade da aprendizagem dos estudantes e com o bem-estar de todos os seus usuários.

Para o melhor aproveitamento da luz natural nos ambientes da escola, o projeto buscou considerar:

- o modo pelo qual as formas, superfícies e cores se combinam para que a luz do dia seja melhor distribuída nos ambientes;

- o uso do vidro nas fachadas, minimizando sua utilização nas fachadas oeste e maximizando nas fachadas sul;

- a utilização de um sistema de aberturas, que conjuga janelas baixas e altas, adequado à iluminação natural uniforme, ventilação cruzada e contato visual com o exterior (Figura 07);

- a localização de aberturas no alto das paredes para otimizar a distribuição uniforme da luz, que assim penetra mais profundamente nos espaços;

- o gerenciamento da entrada de luz nos ambientes, com dispositivos de sombreamento estrategicamente colocados para bloquear a radiação solar direta sobre portas e janelas

- a maximização da entrada de luz uniforme nos ambientes e áreas de circulação, através de aberturas criadas pelo jogo de coberturas;

- a entrada de luz por duas direções diferentes, para reduzir reflexos desconfortáveis e equilibrar a distribuição da luz;

- o fornecimento de luz natural adequada tanto ao tipo de tarefa e ou atividade a ser realizada como 
para elementos que merecem atenção ou destaque (como os painéis de exposição dos trabalhos dos alunos. por exemplo);

- o direcionamento das aberturas dos ambientes internos para áreas externas com vegetação e áreas de atividades diversas, propiciando descanso visual e estímulo à utilização dessas áreas para diversas aprendizagens;

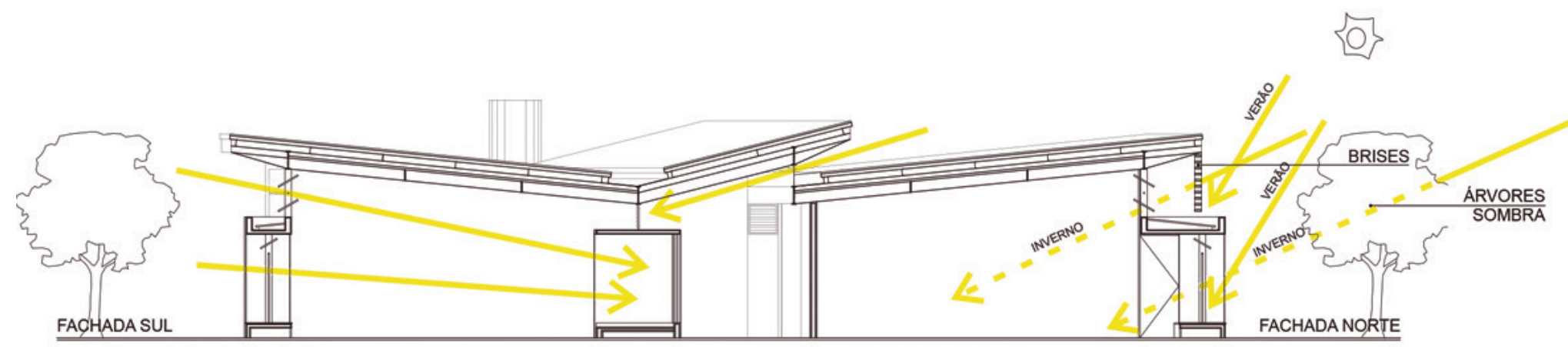

Figura 7

Iluminação natural

Assim como a iluminação natural, a ventilação natural também é um dos fatores essenciais no processo de ensino-aprendizagem, contribuindo para um ambiente escolar saudável. Edifícios naturalmente ventilados proporcionam ambiente térmico com condições internas ideais aos seus usuários, e podem aliviar ou até mesmo eliminar sérios problemas de saúde relacionados à formação de mofo e à quantidade excessiva de tempo que as pessoas passam em ambientes condicionados.

Para permitir a fluidez dos ventos, o projeto proposto buscou:

orientar a maioria das aberturas do edifício em relação à incidência do vento predominante;

localizar as aberturas em direções e alturas diferentes, para possibilitar a passagem do vento em todos os ambientes do edifício

estabelecer o uso da ventilação cruzada, pois ela utiliza princípios de fluxos de ar natural, para que o ar fresco circule no ambiente, dando aos usuários maior controle sobre a qualidade do ar que necessitam (Figura 08, Figura 09). 

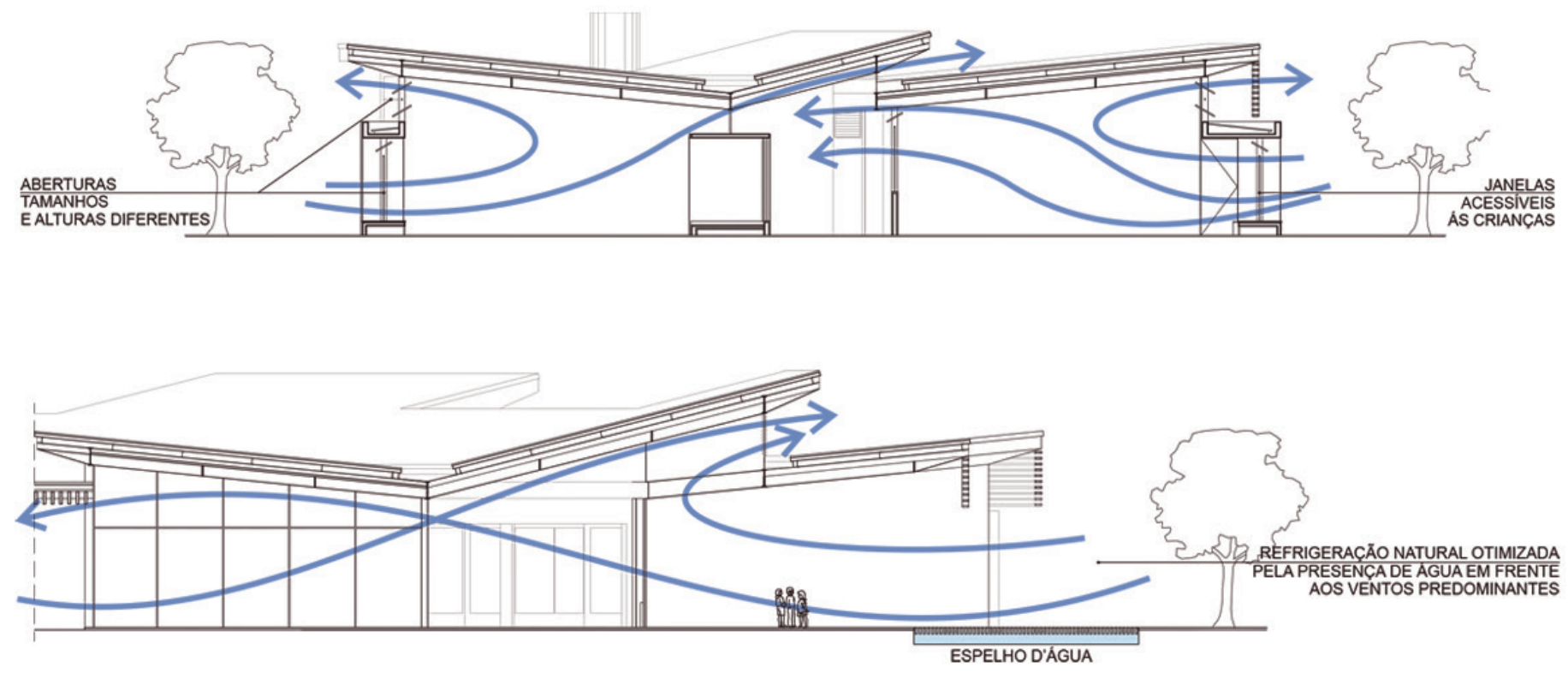

Figura 8

Ventilação natural

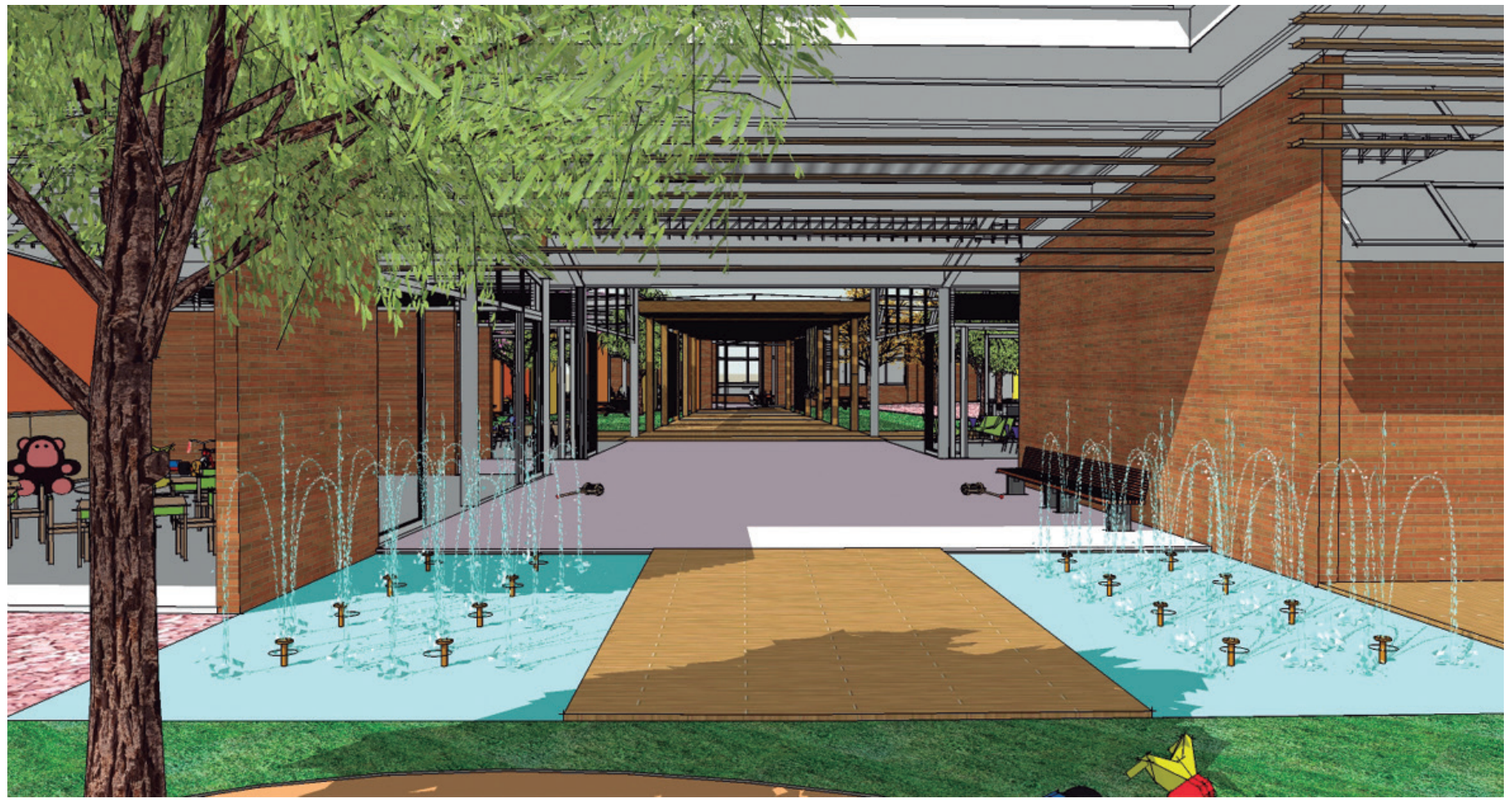

Figura 9

Refrigeração natural otimizada pele presença de água em frente aos ventos dominantes

\section{Ambientes acolhedores}

Além de reduzir o estresse infantil, causado pela permanência em ambientes diferentes dos domésticos, a escola que oferece ambientes acolhedores faz com 
que os estudantes e a comunidade se sintam pertencentes ao espaço escolar.

Neste sentido, é importante que as escolas de educação infantil ofereçam, desde a entrada, ambientes convidativos, parecidos com os domésticos, com mobiliário confortável e espaços apropriados tanto para receber as crianças, professores e funcionários como para receber a comunidade.

A solução adotada neste projeto oferece e/ou propicia:

- área sombreada e equipada com bancos na entrada da instituição;

- ser ou ter elemento significativo que identifique a escola no contexto da comunidade adjacente;

- jardins frontais arborizados;

- espaço de transição amigável e coberto que oferece proteção contra a chuva;

- entrada ou recepção ampla, que serve como espaço de socialização para pais, crianças e funcionários, e que oferece visão para outras áreas da escola, onde é possível observar as crianças em aprendizagens ativas, estímulo para as novas crianças que chegam à escola;

- secretaria próxima da recepção, para facilitar o gerenciamento da entrada dos pais, visitantes e crianças; para otimizar o atendimento da comunidade; com aberturas voltadas para a rua e para espaços internos da escola, propiciando a segurança e a supervisão passiva das crianças;

- sala da direção e ou coordenação próxima da secretaria, para otimizar o controle e o funcionamento da escola; com janelas para o exterior, possibilitando a segurança ("olhos na rua"); mobiliada para o trabalho dos coordenadores e para receber as crianças e ou seus pais em atendimento personalizado;

- locais e painéis de exposição dos trabalhos das crianças, visíveis e próximos da entrada e também espalhados pelos outros ambientes;

- atmosfera doméstica nas salas de atividades infantis, utilizando tapetes, assentos macios, almofadas, cores e texturas; 
- espaços que, além de permitirem a circulação, também servem aos objetivos de desenvolvimento social e emocional das crianças;

- espaços de interação social para crianças e professores (pátios, espaços externos, cozinha e refeitório);

- área externa sombreada, mobiliada e equipada com brinquedos;

- ambientes de trabalho ergonômicos e flexíveis para professores, com espaço para se reunirem em equipes para preparação de aulas e projetos; espaços para trabalho individual, com computadores de colo ou de mesa; espaço para café e leitura; armários para guardar objetos de trabalho e objetos pessoais; janelas com vistas para a rua e para ambientes internos da escola;

- mobiliário de boa qualidade, diversificado, confortável e ergonômico, adequado às várias faixas etárias infantis e aos adultos; que acomode as diferentes atividades; com assentos macios e confortáveis espalhados pelos ambientes da escola, a fim de deixar o espaço mais humanizado e menos institucional;

- criar recantos interessantes, sem sacrificar a segurança das crianças.

\section{Circulação como um passeio de aprendízagem}

Rompendo com o antigo corredor escolar, carregado de salas dos dois lados, e considerando o novo modelo educacional, que requer espaços variados, adaptáveis e flexíveis para conter as várias modalidades de aprendizagens, propôs-se como diretriz projetual substituir esse antigo corredor por um passeio de aprendizagem.

Este passeio deve ser amplo o suficiente para não se parecer com um corredor e aberto para áreas externas (Figura 10), para que as pessoas não se sintam fechadas ao circularem por ele, e deve funcionar como uma artéria social, ou seja, como um lugar para encontros informais, brincadeiras, conversação espontânea e movimento sem pressa.

No projeto proposto, o passeio de aprendizagem se estabelece como um elemento de ligação entre os vários ambientes da escola e define um percurso através do qual é possível alternar espaços-passagem e espaços-vivência (Figura 11). 
Seu desenho curvo e aberto e sua ambiência clara e iluminada estimulam os usuários a percorrê-lo, possibilitando-Ihes o sentimento de surpresa e descoberta, e, ao mesmo tempo, oferece oportunidades e incentivos para que eles parem ao longo do caminho, participem de atividades que estejam ocorrendo, ou observem o que está acontecendo nas salas e ambientes externos aos quais o passeio está conectado.

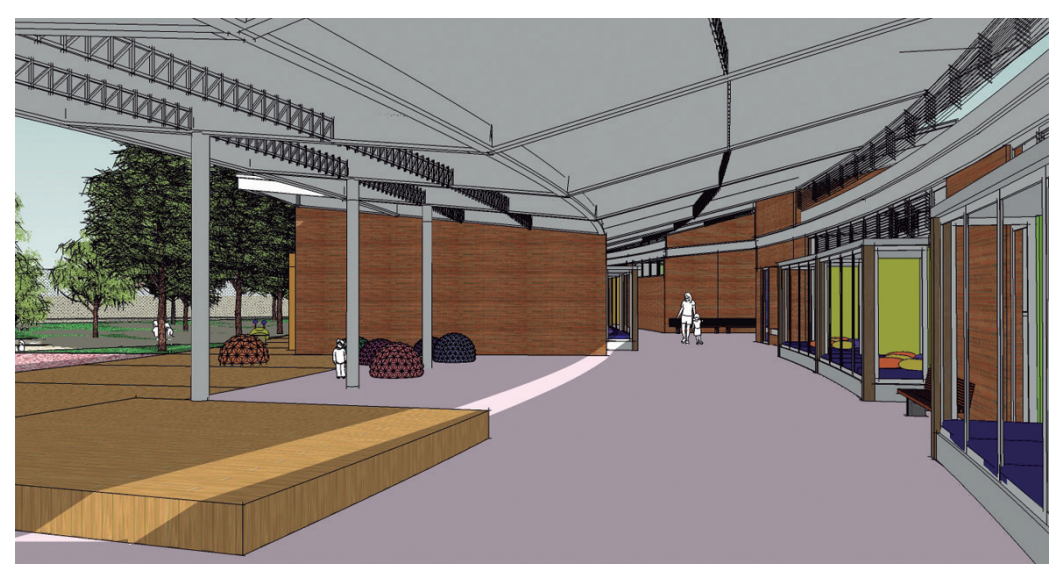

Figura 10

Circulação com um passeio de aprendizagem: vista pátio central

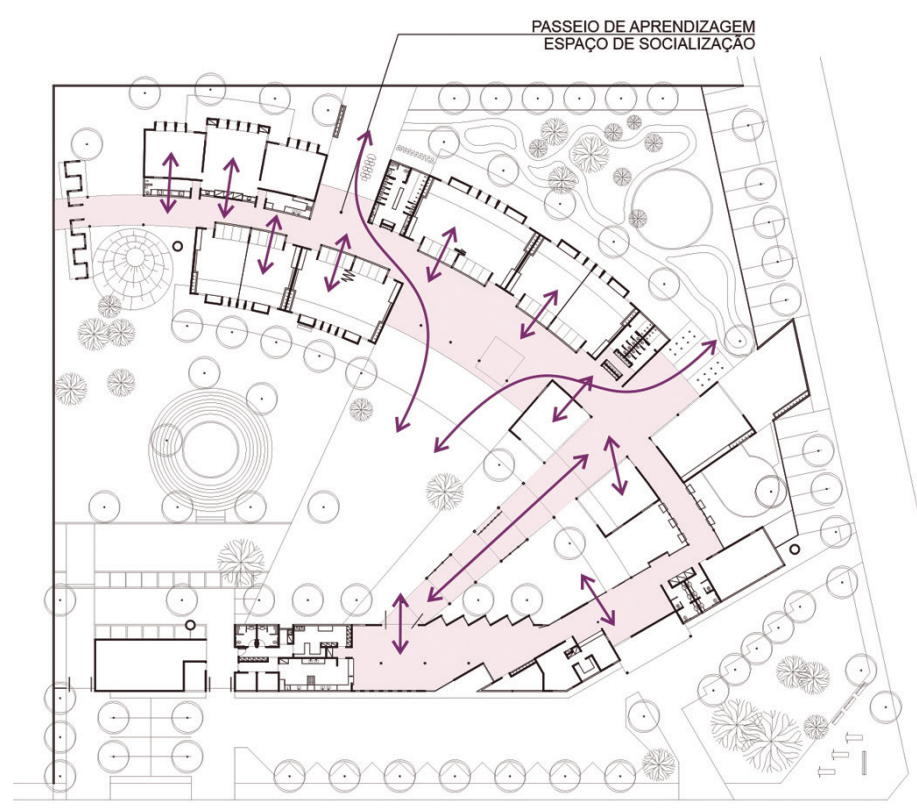

\section{Adaptabilidade/flexibilidade/ variedade}

O conceito de polivalência não se restringe apenas a espaços flexíveis, com portas de correr e painéis mó- 
veis, mas ajuda a pensar o espaço de forma que este possa ser modificado de acordo com o tipo de atividade e de relação desejável, através das ideias de adaptabilidade, flexibilidade e variedade.

A adaptabilidade considera princípios ergonômicos e pode ser obtida com elementos construtivos que podem ser facilmente removíveis e desmontáveis. Esta ideia permite mudanças espaciais por um período de anos ou décadas.

A flexibilidade permite que os próprios usuários transformem o espaço, situação possível através da utilização de painéis móveis e acústicos, grandes portas e aberturas e mobiliário móvel. A flexibilidade permite mudanças por um dia ou por semanas, dependendo do tipo de atividade que será desenvolvida.

A variedade permite que os usuários mudem a qualidade do espaço, simplesmente se movendo de um ambiente para outro. Esta ideia está centralizada no conceito de espaços polivalentes, que permitem uma inter-relação entre as atividades que estão sendo desenvolvidas e os ambientes que se adaptam a elas.

Considerando estas questões, propôs-se para este projeto:

- que as salas de atividades infantis tenham alguns de seus limites definidos por painéis acústicos deslizantes que permitem a ligação, quando desejada, entre elas (Figura 12);

- refeitório articulado e integrado ao ambiente externo, possibilitando arranjo diferenciado e disponível para pequenos e grandes grupos, em diferentes tipos de atividades (Figura 13);

- que as salas especiais tenham grandes portas de vidro deslizantes, que permitem a conexão delas com o passeio de aprendizagem e com os terraços externos, estendendo-se, desta forma, a aprendizagem para os ambientes externos, aumentando a flexibilidade dos espaços e a possibilidades de variação no seu uso (Figura 14)

- variedade de espaços externos, para dar suporte às várias modalidades de aprendizagens, especialmente jogos e brincadeiras. 

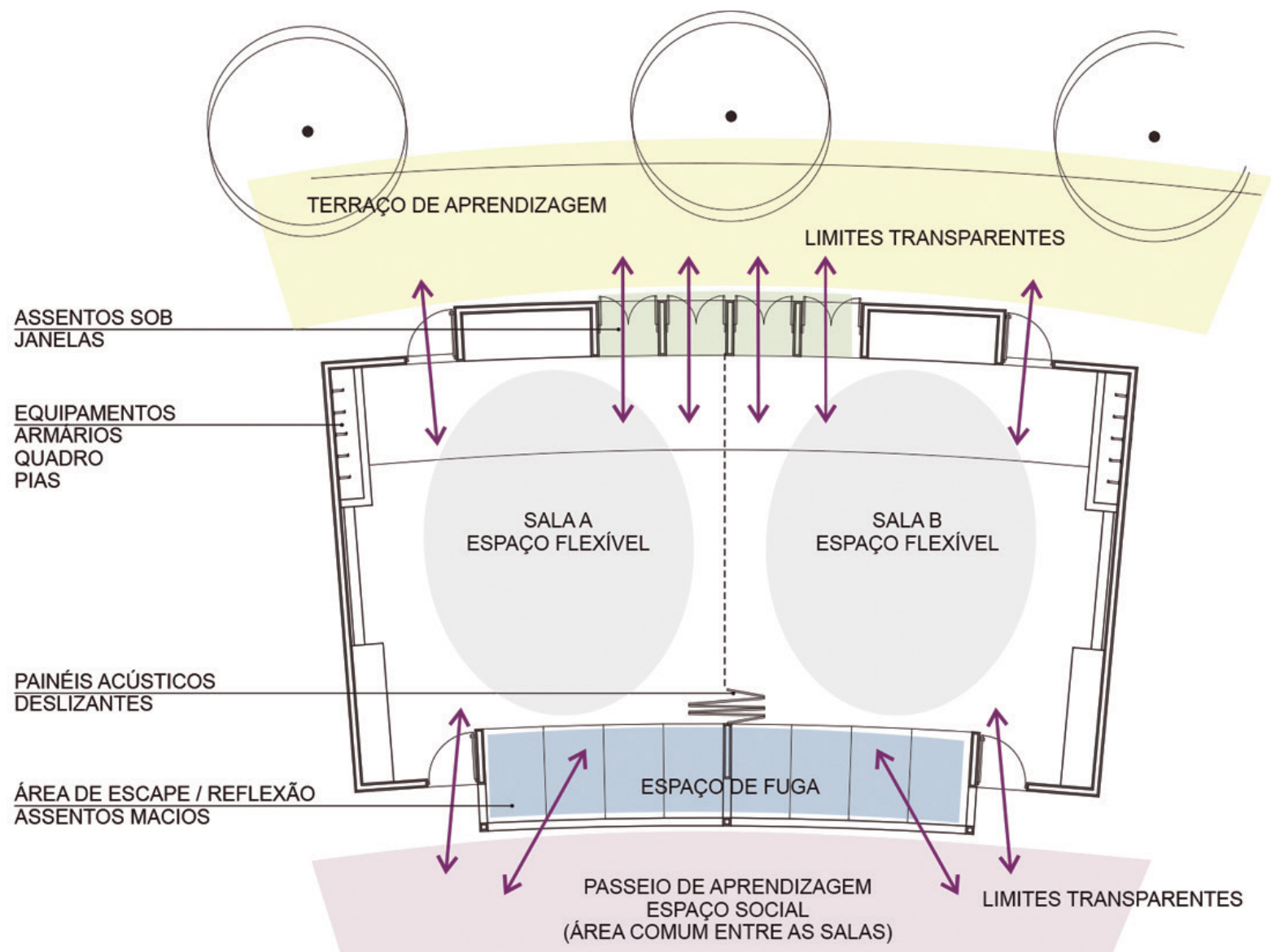

Figura 12

Adaptabilidade/flexibilidade/variedade: salas de atividades

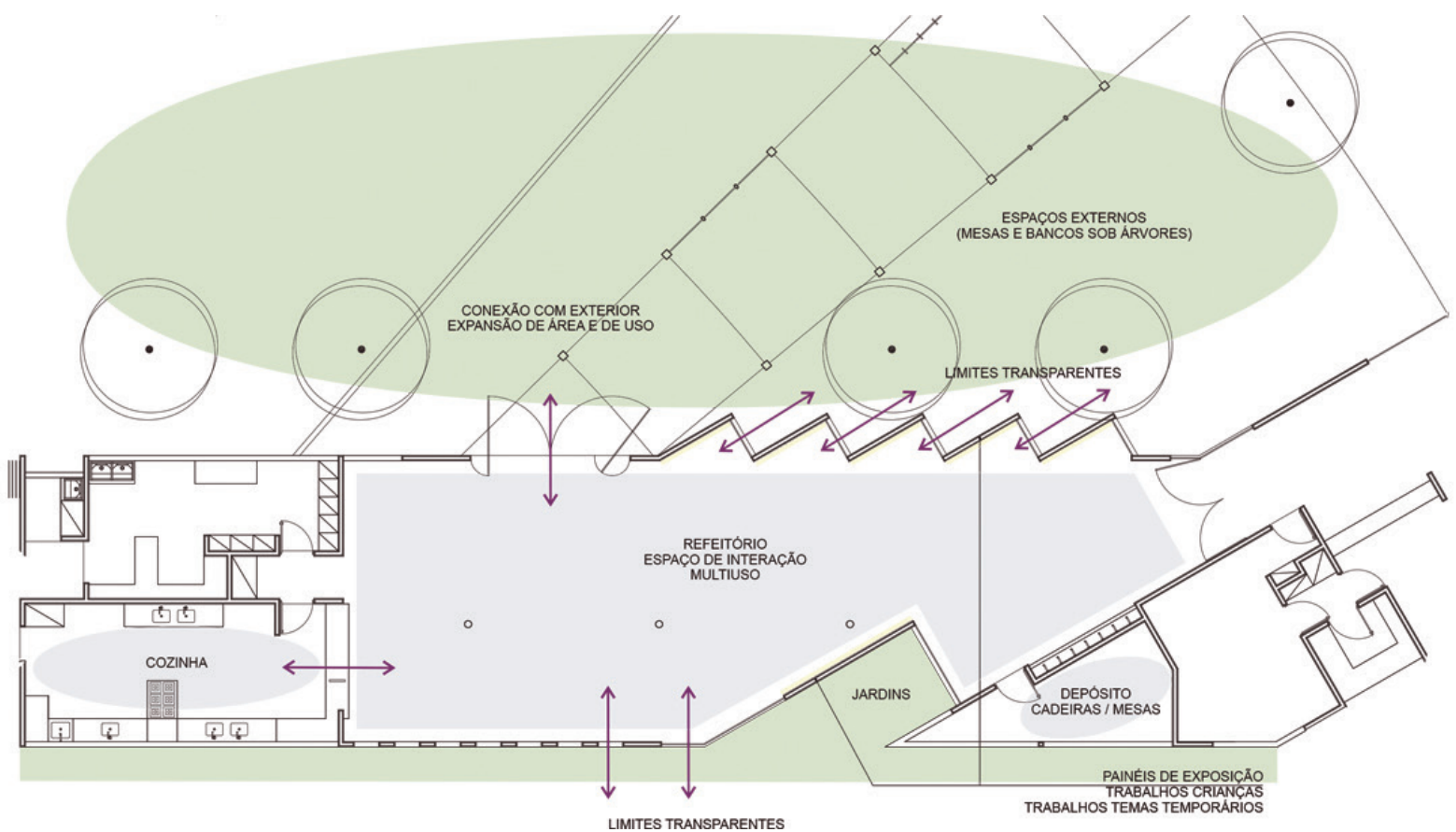

Figura 13

Adaptabilidade/flexibilidade/variedade: refeitório 


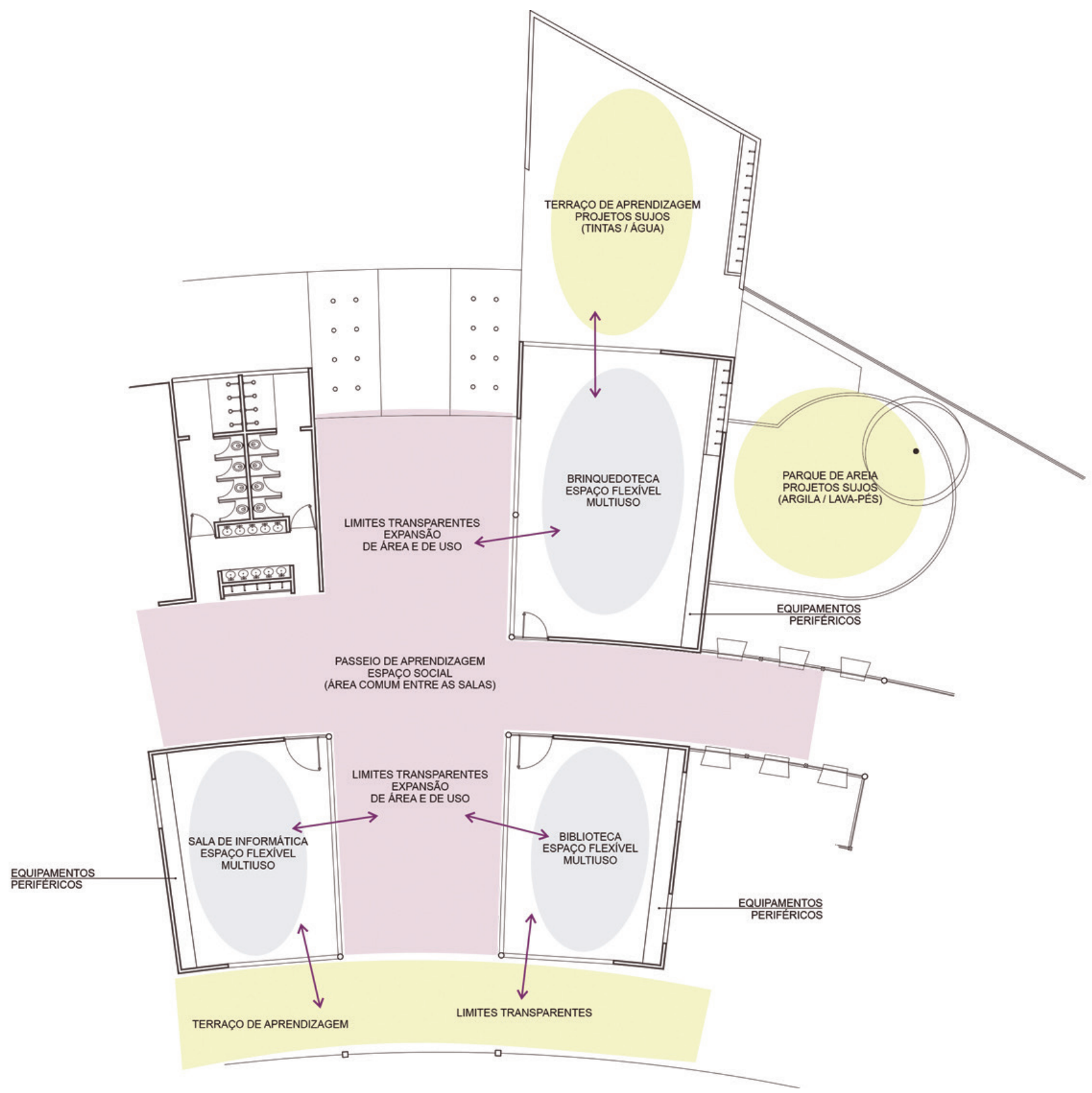

Figura 14

Adaptabilidade/flexibilidade/variedade: salas especiais e refeitório

\section{Transparência e supervisão passiva}

A transparência é um dos conceitos fundamentais no projeto de escolas, pois transmite a ideia que a aprendizagem deve ser visível e supervisionada passivamente.

Neste projeto, transparência e supervisão passiva se relacionam na medida em que, juntas, propiciam grandes níveis de visibilidade (Figura 15) entre os espaços de aprendizagem, criando assim sensação de abertura, aumento da iluminação natural, segurança ("olhos na rua") e facilidade na supervisão passiva dos professores ("olhos nas crianças"). 


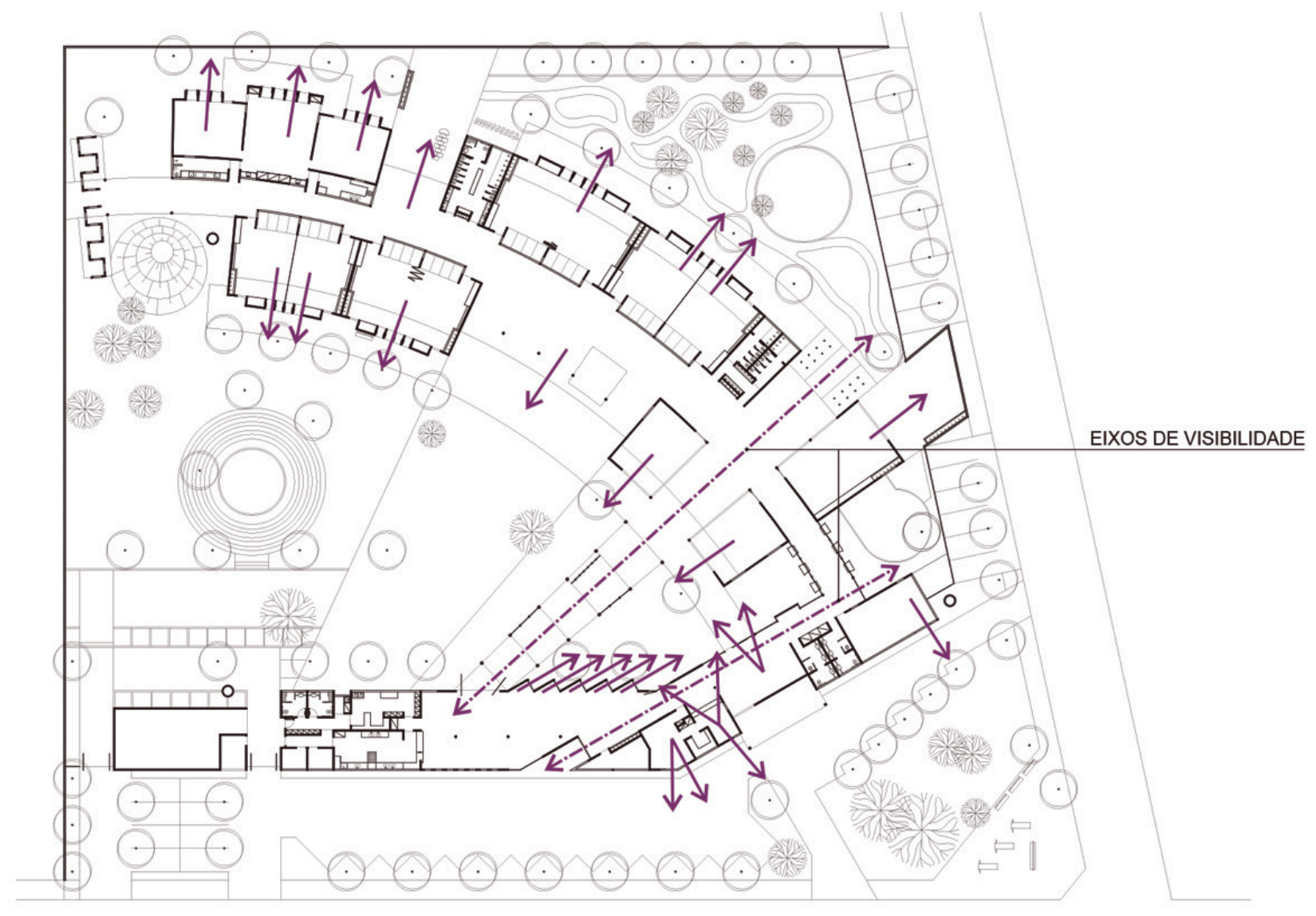

Tendo em vista o cuidado que se deve ter com as crianças pequenas, as soluções adotadas no projeto contemplam as seguintes questões:

- providenciar grandes aberturas transparentes para os ambientes administrativos, para permitir o monitoramento da entrada e de outras áreas internas da escola e para aumentar o sentimento de segurança;

- providenciar acesso visível da área de entrada para outras áreas de atividades infantis, permitindo que o propósito da proposta pedagógica da escola seja visto;

- providenciar visibilidade entre as salas de atividades infantis e os terraços externos e entre elas e o passeio de aprendizagem, permitindo a supervisão passiva e estimulando os professores a utilizarem essas áreas para a realização de várias atividades; 
- trazer iluminação natural aos corredores, para reduzir o sentimento de fechamento e criar vistas interessantes de diferentes partes da escola, possibilitando o sentimento de surpresa à medida que os usuários se movem no edifício;

- fornecer não apenas transparência visual, mas transparência física, através de portas e painéis opacos e acústicos, para favorecer a mistura de usos dos ambientes;

- fornecer transparência entre áreas internas e externas, trazendo a luz do dia para dentro dos ambientes e tornando-os mais abertos, convidativos, animadores e conectados ao meio natural (Figura $16)$;

- criar eixos de visibilidade que permitem a melhor identificação dos espaços.

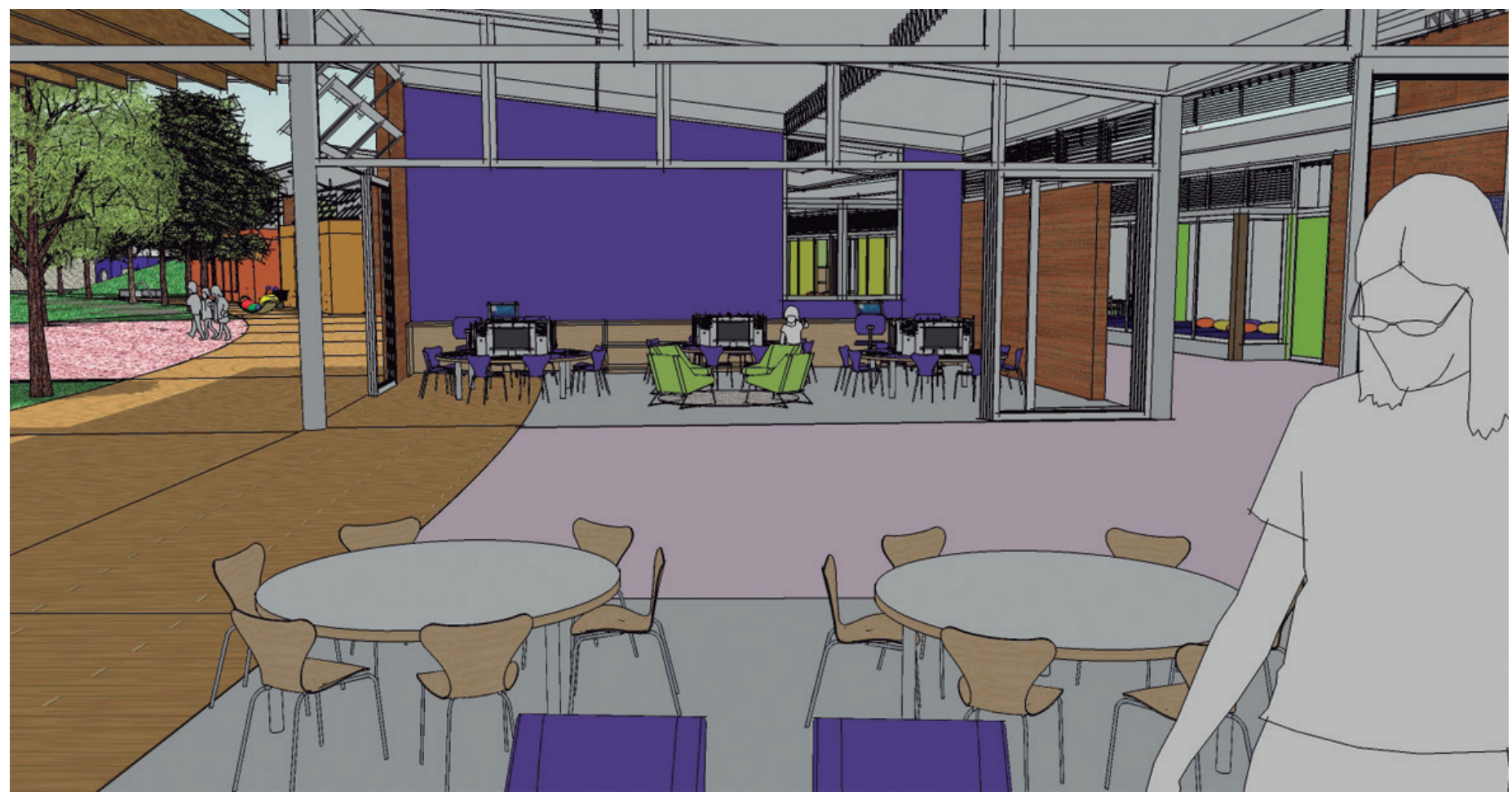

Figura 16

Visibilidade entre os ambientes da escola

\section{Arquitetura que ensina/ sustentabilidade}

A arquitetura sustentável é um dos elementos essenciais no projeto de uma escola. Seu discurso revela uma abordagem sábia, que procura minimizar os efeitos destrutivos da construção na natureza, absorver 
fontes de energia natural para minimizar o consumo de combustíveis fósseis, utilizar materiais regionais renováveis e ou recicláveis e não poluentes e, ainda, economizar o consumo de água no edifício, capturando e utilizando a água da chuva e minimizando a erosão e o escoamento de água no lugar.

Nessa perspectiva, alguns princípios de sustentabilidade foram adotados como diretrizes para a elaboração deste projeto:

- conexão interior/exterior;

- iluminação natural;

- ventilação natural;

- dispositivos de sombreamento, como árvores e brises;

- sistema construtivo que deixa transparecer seus elementos de estrutura e vedação;

- construção de reservatórios para o reaproveitamento da água da chuva;

- reaproveitamento da água "cinza" de chuveiros e pias para irrigação subterrânea de jardins (Figura 17);

- captação de energia solar para esquentar a água de chuveiros e pias;

- utilização de pisos externos permeáveis como pedra portuguesa, tabuados de madeira, areia e grama;

- instalação de arquibancadas (arena verde) assentadas sobre a grama, considerando os desníveis naturais do terreno;

- preservação de árvores existentes no sítio.

Juntos, estes princípios expressam uma configuração dinâmica que incentiva e induz aprendizagens sobre arquitetura, construção e ciência ambiental, em harmonia com a natureza. 

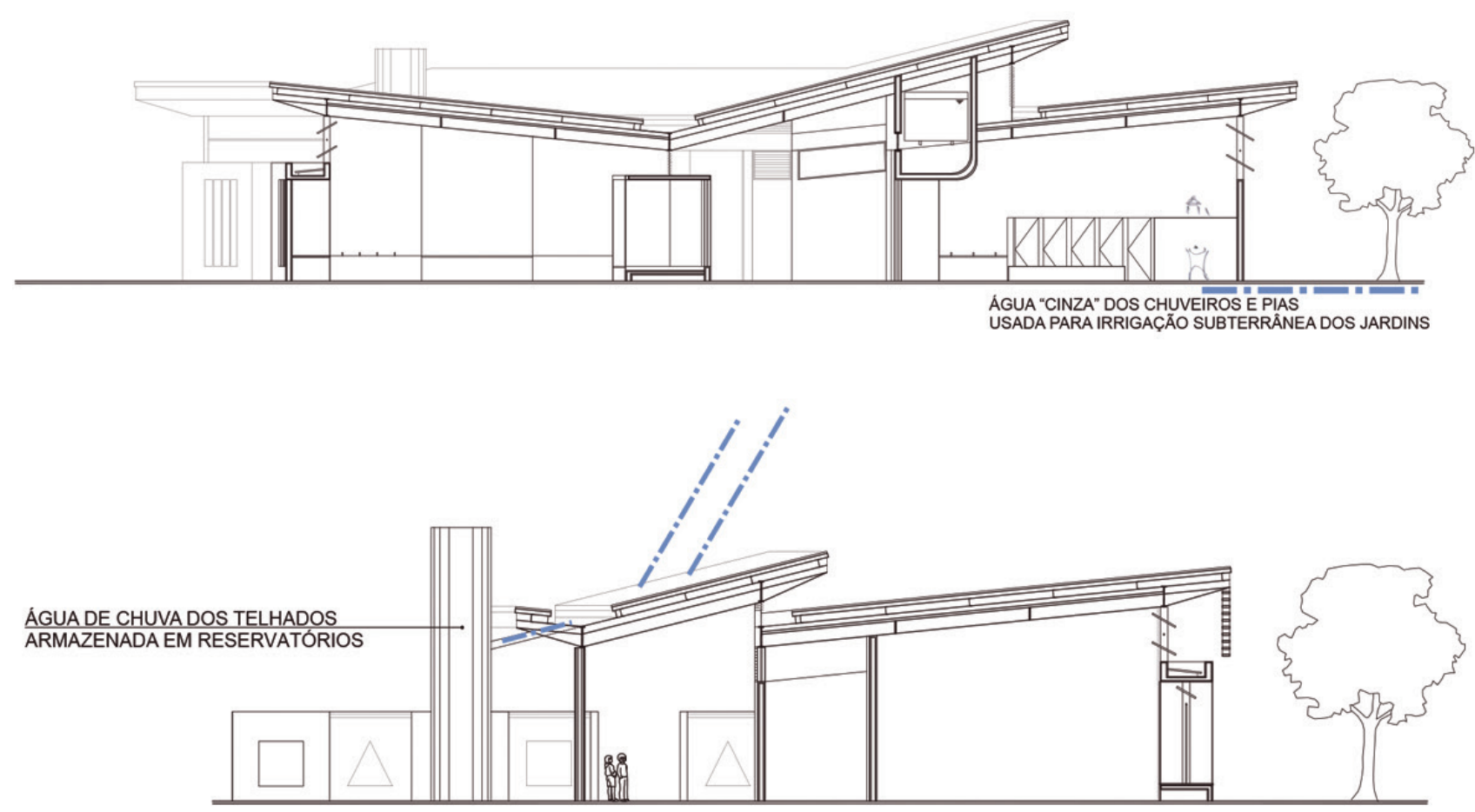

Figura 17

Reaproveitamento da água "cinza" e da chuva

\section{Espaços externos e incentivos lúdicos}

Crianças pequenas aprendem brincando e necessitam de espaços generosos e adequados para se desenvolverem (Figura 18).

Propôs-se para este projeto incentivos lúdicos e diversificados espaços externos $\left(23 \mathrm{~m}^{2} /\right.$ criança), que permitem a socialização e estimulam o imaginário e a criatividade das crianças:

- terraços de aprendizagens externas integrados às salas de atividades e às salas especiais;

- praça central configurada por uma grande área pavimentada com pedra portuguesa, espaços gramados e parque de areia com brinquedos;

- lugares para performances teatrais e musicais: arena verde e pátios;

- painéis para atividades com tintas, instalados nos muros dos pátios laterais;

- espelho d'água com duchas, para banhos no verão;

- parques de areia, com brinquedos que estimulam a atividade física; 
- trilhas para caminhadas e passeios de bicicletas e velocípedes;

- jardins ornamentais, para estimular experiências com a natureza e seus processos;

- horta, para propiciar trabalho colaborativo entre crianças, professores e comunidade;

- pomar;

- morro gramado para brincadeiras de escalada e do "faz de conta";

- árvores incorporadas à estrutura recreativa;

- parques de areia, com brinquedos de madeira;

- mobiliário para alimentação casual, trabalhos em equipe, espalhado nos jardins;

- tanques de areia e terra, para brincadeiras de modelar, com baldes e pás;

- pergolado, equipado com telas e cordas para brincadeiras de pular, trepar e escalar, que faz a ligação entre o refeitório e o passeio de aprendizagem, configurando-se em um eixo lúdico que termina nas duchas do espelho d'água e na trilha para caminhadas e passeio de bicicleta;

- esquema rico e variado de cores nos ambientes internos e externos, para minimizar o caráter institucional e estimular os processos de aprendizagens;

- elementos visuais de destaque para atrair e incentivar a movimentação dos usuários;

- variedade de níveis de iluminação, obtido por meio de diferentes tipos e tamanhos de janelas e aberturas;

- variedade de texturas (madeira, pedra, vidro, metal, concreto, areia, terra, grama, etc.) nos pisos, paredes e elementos construtivos do edifício;

- viveiro de pássaros e toca de animais;

- casa de bonecas (Figura 19);

- "túnel de vidro" com aberturas circulares coloridas acessíveis às crianças; 
- palco/banco, onde as crianças podem se envolver em atividades do "faz de conta" e/ou simplesmente se encontrarem para conversar;

- desníveis e acidentes no terreno, para despertar o sentimento de aventura nas crianças.

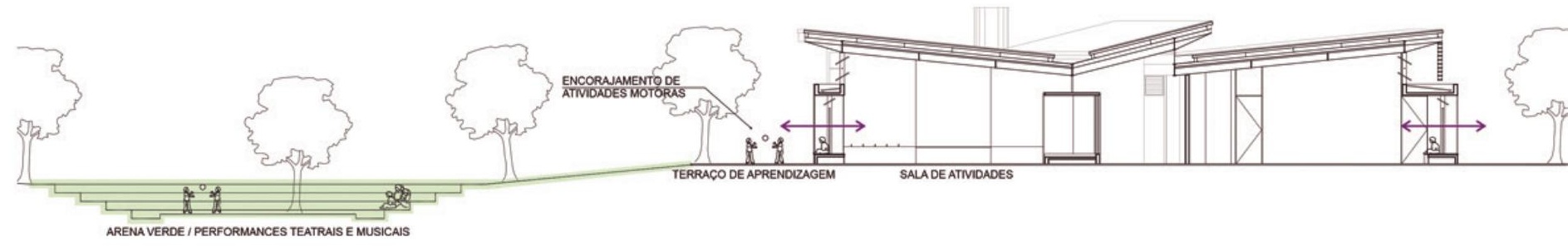

Figura 18

Espaços externos e incentivos lúdicos: encorajamento de atividades lúdicas
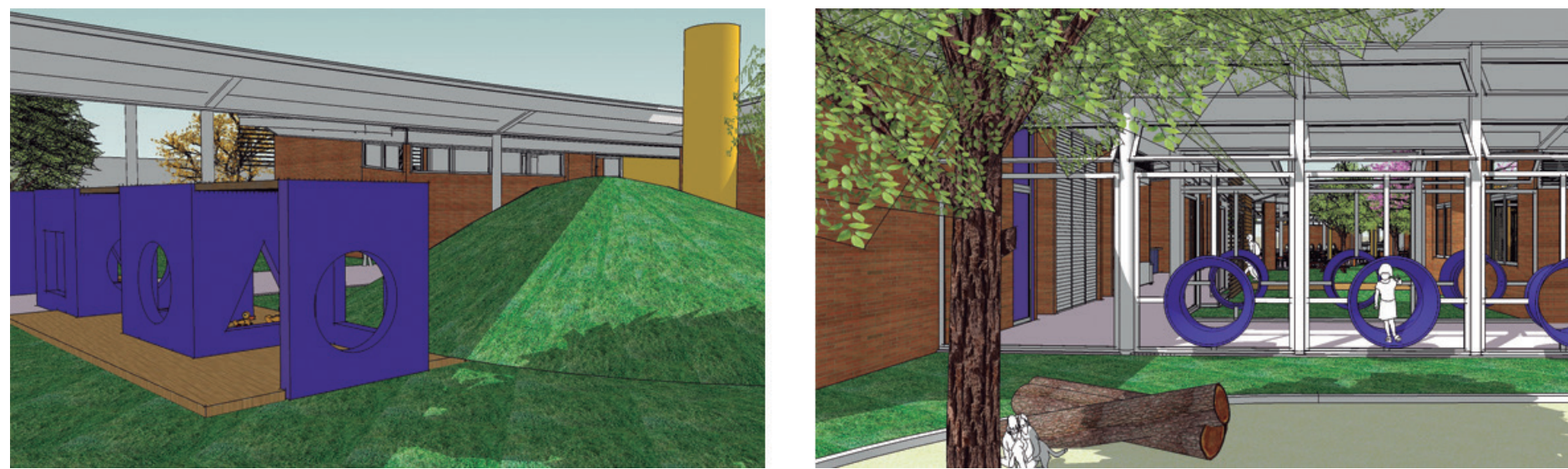

Figura 19

Espaços externos e incentivos lúdicos: casa de bonecas e túnel de vidro

\section{Materiais, texturas e cores como elementos de identidade visual}

Visto que o desenvolvimento cognitivo das crianças pode ser afetado pela interação delas com o espaço e considerando que ambientes acolhedores, iluminados, ventilados, influenciados pelo meio natural e pelas possibilidades de vistas para o exterior são ainda mais enriquecidos quando se utiliza diferentes superfícies, materiais, texturas e cores em suas estruturas, foi importante para a concepção deste projeto explorar as qualidades materiais e plásticas dos elementos de estrutura e de vedação em seus aspectos naturais.

Desta forma, elegeu-se o tijolo maciço para vedações externas; o concreto armado para os pilares "soltos" 
da estrutura; o metal para as vigas e treliças que compõem a estrutura do edifício e para as telhas termoacústicas da cobertura; a madeira para os elementos do pergolado, pilares que participam da configuração das salas de atividades, alguns pisos e para painéis de exposição dos trabalhos das crianças, e a pedra basáltica para as arquibancadas da arena.

A opção pela manutenção dos materiais aparentes, principalmente o tijolo maciço, o concreto armado, o metal e a madeira, não só intensifica a percepção espacial dos usuários da escola, como afirma um compromisso ético-estético com a verdade construtiva do edifício, que se torna um elemento didático, que revela, de forma sincera, o modo como foi construído.

A cor, elemento lúdico por excelência, também foi utilizada como elemento facilitador de identidade espacial. A estratégia utilizada no projeto para facilitar a identificação dos ambientes pelas crianças foi destacar volumes e superfícies pelo seu uso.

Apesar da variedade de elementos que compõem os volumes do edifício, a integridade e o caráter unitário do todo foram mantidos, e o resultado é a percepção clara dos ambientes da escola pelos seus usuários e pela comunidade.

\section{Conclusão}

A pesquisa não teve como propósito estabelecer normas para a elaboração de projetos de escolas para a educação infantil. A elaboração do anteprojeto apresentado, definida segundo os conceitos abordados e as diretrizes propostas, complementa a tese de que a dimensão lúdica dos espaços escolares - aquelas qualidades que os tornam mais interativos, atraentes, estimulantes e acolhedores - contribui para um ambiente que promove a relação entre seus usuários, corresponde às necessidades da criança, participa e interage com a construção de seu conhecimento.

Algumas das diretrizes determinadas configuram as sugestões contidas na legislação e na literatura pertinentes às escolas de educação infantil, outras caracterizam soluções de problemas detectados nos estudos de caso da pesquisa e, finalmente, algumas delas representam uma tentativa de acrescentar inovações na área.

De qualquer modo, é importante lembrar que essas diretrizes e esses conceitos - acolhimento, complexidade, polivalência, transparência e ludicidade - podem ser úteis quando se deseja elaborar projetos 
de escolas cujo foco é a aprendizagem, sobretudo a aprendizagem lúdica, que considera tanto o brincar quanto o espaço, elementos fundamentais para o desenvolvimento infantil.

Finalmente, as reflexões apresentadas neste trabalho reforçam a ideia de que o projeto de arquitetura, desde a sua concepção à sua resolução, é uma atividade que envolve teoria e prática, relacionando questões conceituais com diretrizes projetuais e suas soluções espaciais.

\section{Referências}

BASTIANINI, M. CHICCO, E. MELA, Alfredo. O espaço e a criança: em busca de segurança e aventura; in, DEL RIO, Vicente, DUARTE, C. R., RHEINGANTZ, Paulo A. Projeto do lugar: colaboração entre psicologia, arquitetura e urbanismo. Rio de Janeiro: Contra capa livraria / PROARQ, 2002.

BOMTEMPO, Edda, HUSSEIN, Carmen L., ZAMBERLAN, Maria A. T. Psicologia do brinquedo: aspectos teóricos e metodológicos. São Paulo: Nova Estela: Editora da Universidade de São Paulo, 1986.

BRASIL, Lei de Diretrizes e Bases da Educação Nacional (LDB). Lei Federal no 9.394, de 26/12/1996.

BRASIL, Constituição da República Federativa do Brasil. Lei Federal de 05/10/1988. Brasília: Senado Federal, 2000.

BRASIL, CNE/CEB, Plano Nacional de Educação (PNE). Lei Federal no 10.172, de 9/01/2001.

. Diretrizes Curriculares Nacionais para a Educação Infantil. Resolução no 01, aprovado em 07/04/1999b).

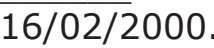

Diretrizes operacionais para a Educação Infantil. Parecer nº 04, aprovado em

BRASIL, MEC, COEDI, Subsídios para credenciamento e funcionamento de instituições de educação infantil. Brasília: MEC/SEF/DPEF/COED, 1998a, 2v.

3v.

. Referencial Curricular Nacional para a Educação Infantil. Brasília: MEC/SEF, 1998b.

BRASIL, MEC, SEB, DPE, COED. Política Nacional de Educação Infantil: pelo direito das crianças de zero a seis anos à educação. Brasília: MEC/Secretaria de Educação Básica/ DPE/COEDI, 2005a.

- Parâmetros Nacionais de Infraestrutura para Instituições de Educação Infantil. Brasília: MEC/Secretaria de Educação Básica/ DPE/COEDI, 2005b.

BRASIL, MEC, SEB. Parâmetros Básicos de Infraestrutura para Instituições de Educação Infantil. Brasília: MEC, SEB, 2006a.

. Parâmetros Básicos de Infraestrutura para Instituições de Educação Infantil: Encarte 1. Brasília: MEC, SEB, 2006a.

Parâmetros Nacionais de Qualidade para Instituições de Educação Infantil: Brasília: MEC, SEB, 2006b, 2v. 
BROUÈRE, Gilles. Jogo e educação; trad. Patrícia C. Ramos. Porto Alegre: Artes médicas, 1998.

Brinquedo e cultura. Revisão técnica e versão brasileira adaptada por Gisela Wajskop. São Paulo: Cortez, 2004

BUFFA, Ester e PINTO, Gelson de Almeida. Arquitetura e educação: organização dos grupos escolares paulistas, 1893/1971. São Carlos: Edufscar, 2002.

CASTRO, Fabíola Fiusa Malerbi. Relação espaço-aprendizado: uma análise do ambiente pré escolar. 2000. 169 f. Dissertação de Mestrado, FAU/USP, 2000.

CENTRO INTERNACIONAL DA INFÂNCIA. O desenvolvimento da criança do nascimento aos seis anos: conhecê-la melhor para ajudá-la; tradução de Antônio Fernandes. São Paulo: Livraria Pioneira Editora, 1983.

CEPPI, Giulio; ZINI, Michelle. Children, spaces, relations: metaproject for environment for young children. Reggio Children; Domus cademy Resarch Center.

COELHO NETO, J. Teixeira. A construção do sentido na arquitetura. São Paulo: Editora perspectiva S. A., 1979.

DUDEK, Mark. Schools and Kindergartens. Birkhauser Verlag AG. 2008.

EDWARDS, L. TORCELLINI, P. A literature reniew of the effects of natural light on building occupants. National Renewable Energy Laboratory - NREL, Colorado, jul. 2002

ELALI, Gleice A. Ambientes para educação infantil: um quebra cabeça? Tese de doutorado. São Paulo: FAUUSP, 2002.

FEDRIZZI, Beatriz. A organização de pátios escolares grandes e pequenos; in DEL RIO, Vicente, DUARTE, C. R., RHEINGANTZ, Paulo A. Projeto do lugar: colaboração entre psicologia, arquitetura e urbanismo. Rio de Janeiro: Contra Capa Livraria / PROARQ, 2002, p.221-229.

FORNEIRO, Lina Iglesias. A organização dos espaços na educação infantil

FRAGO, Antônio Viñao, ESCOLANO, Agustín. Currículo, espaço e subjetividade: a arquitetura como programa. Rio de Janeiro: DP\&A Editora, 2001.

FRIEDMANN, Adriana. Brincar: crescer e aprender - O resgate do jogo infantil. São Paulo: Moderna, 1996.

HALL, Edward T. A dimensão oculta; tradução de Sonia Coutinho. Rio de Janeiro: F. Alves, 1989.

HERTZBERGER, Herman. Lições de Arquitetura. São Paulo: Martins Fontes, 1996.

HUIZINGA, Johan. Homo Ludens: o jogo como elemento da cultura; tradução de João Paulo Monteiro. São Paulo: Perspectiva, 1980.

JACOBS, Jane. Morte e vida nas grandes cidades. São Paulo: Martins Fontes, 2000.

KISHIMOTO, Tizuko M. (Org). O brincar e suas teorias. São Paulo: Pioneira, 1998 (Org). Jogo, brinquedo, brincadeira e a educação. São Paulo: Cortez, 2002. . Jogos infantis: o jogo, a criança e a educação. Petrópolis: Vozes, 1993.

KOROSEC-SERFATY, P. Experience and Use of the Dwelling. In: ALTMAN; WERNER, C. M. (Ed.). Home Environments. New York: Plenum Press, 1985. p. 65-83. 
LIMA, Mayumi W. Souza. A cidade e a criança. São Paulo: Nobel, 1989.

Arquitetura e educação. São Paulo: Studio Nobel, 1995.

LOFT Publications. Kindergartens, Schools and playgrounds. Editorial coordination: Cristina Paredes Benítez, 2007.

LYNCH, Kevin. Imagem da cidade; tradução Jefferson Luiz Camargo. São Paulo: Martins Fontes,1997.

MALARD, Maria Lúcia. Os objetos do cotidiano e a ambiência. In: $2^{\circ}$ Encontro nacional de conforto no ambiente construído, ANAIS. Florianópolis: ANTAC. ABERGO. SOBRAC. 1993

. O método em arquitetura: conciliando Heidegger e Popper. Cadernos de arquitetura e urbanismo. Belo Horizonte. V.8. n.8 (fev). 2001, p. 128-154.

MAZZILLI, Clice de T. Sanjar. Arquitetura lúdica. 2003. 387 f. Tese de doutorado. São PauIo: FAUUSP, 2003.

MUELLER, Cecília, Matos. Espaços de ensino-aprendizagem com qualidade ambiental: o processo metodológico para elaboração de um anteprojeto. São Paulo, 2007, $258 \mathrm{f}$.

NAIR,Prakash. FIELDING, Randall. LACKNEY, Jeffery. The language of school design: Design patterns for 21st century schools. Designshare.com.2009.

PIAGET, Jean. A epistemologia genética. Tradução de Nathanael C. Caixeiro, traduzido do original francês L'épistémologie génétique, Paris, Presses Universitaires de France, 1970. In OS PENSADORES, Abril Cultural,1975a.

. A formação do símbolo na criança: imitação, jogo e sonho, imagem e representação. Trad. Álvaro de Cabral, Christiano M. Oiticica. Rio de Janeiro: Editora LTC, 1990.

. O nascimento da inteligência na criança; tradução de Álvaro Cabral. Rio de Janeiro, Zahar; Brasília, INL, 1975.

Psicologia e pedagogia, $2^{a}$ edição. Rio de Janeiro: Forense, 1972.

PREFEITURA DA CIDADE DO RIO DE JANEIRO, Secretaria Municipal de Urbanismo: Instituto Municipal de Urbanismo Pereira Passos - IPP. Manual para elaboração de projetos de creches na cidade do Rio de Janeiro. Rio de Janeiro, 2000.

PULASK, Mary Ann Spencer. Compreendendo Piaget: uma introdução ao desenvolvimento cognitivo da criança. Tradução de Vera Ribeiro. Rio de Janeiro. Zahar Editores, 1983

RAPOPORT, Amos. Aspectos humanos de la forma urbana. Barcelona: Gustavo Gili, 1978.

ROGERS, Carl R. Liberdade de aprender em nossa época. Belo horizonte: Interlivros, 1978.

RYBCZYNSKY, Witold. A. Casa, pequena história de uma ideia. Trad: Betina Von Staa. Rio de Janeiro: Record, 1986.

SOMMER, R. Espaço pessoal. São Paulo: Editora da Universidade de São Paulo (EDUSP), 1993.

TORNQUIST, Jorrit. Color y luz: teoria y práctica. Barcelona: Gustavo Gili, 2008.

TUAN, Yi-Fu. Espaço e lugar: a perspectiva da experiência. São Paulo: Difel, 1983.

ZABALZA, Miguel A. Qualidade em educação infantil. Porto Alegre: Artmed, 1998.

ZEVI, Bruno. Saber ver a arquitetura. 4a ed. Tradução de Maria Isabel Gaspar, Gaetan Martins de Oliveira. São Paulo: Martins Fontes, 1994 